\title{
An Arts-based research on group sandplay therapy for children in local children's centers who are overly dependent on internet and smartphones experiencing the COVID-19 pandemic era
}

\author{
Park, Sung Min* Jo, Yun ${ }^{* *} \quad$ Jung, Hyun Kyoung ${ }^{* * *}$
}

The purpose of this study is to find a clue of psychological intervention in group sandplay therapy for children in local children's centers who are overly dependent on internet and smartphones experiencing the COVID-19 pandemic era. Art is a process of expressing imagination, and it is in line with the fact that play is a symbolic and creative activity. Therefore, it can be said that children's imaginary play scenes and imaginary stories appearing in sandplay therapy are a form of art. Sandplay enables non-verbal expression, and the unconscious contents expressed by children are useful in understanding children's emotions. In this process, the researcher understands the client through imagination which is the intersubjective method and experiences an accepting relationship where healing and change occur. However, previous studies have limitations in that they approached children's dependence on the Internet and smartphones based on language. Therefore, these researchers conducted an arts-based study from an analytical psychology perspective to understand the experiences of children in local children's centers who are overly dependent on the Internet and smartphones through the group sandplay therapy process. To this end, co-researchers attending the doctoral program in child counseling and psychotherapy have categorized and discussed four themes: 'wanting to be loved', 'suffering from anxiety', 'tolerating being alone/not communicating', 'trying to protect oneself. Finally, it was intended to alleviate the psychological difficulties of children in local children's centers who are overly dependent on internet and smartphones, and to provide an open method for resolving the Internet and smartphone dependence phenomenon.

Keywords : COVID-19 pandemic era, group sandplay therapy, overly dependent on internet and smartphones, Arts-based research

* Main author, Sandplay therapist of Hugmom Psychological Counseling Center (childlove123@naver.com)

** Corresponding author, Ph.D. student, Child Welfare Department at Graduate School of Namseoul University (77734306@hanmail.net)

*** Co-author, Ph.D. student, Child Welfare Department at Graduate School of Namseoul University (kidskidslove@gmail.com) 
Journal of Symbols \& Sandplay Therapy, Vol.12 No.1.

\section{INTRODUCTION}

Various social changes have occurred since the outbreak of COVID-19 in 2020. Social distancing measures was implemented to prevent the spread of the pandemic. Various new lifestyles were created to adapt to environmental changes. These changes also took placed in the daily life of children. The start of the school year was pushed back; social distancing deprived children of the opportunity for a social life. Prolonged online classes naturally increased their access to digital media, which would lead to internet and smartphone overdependency problem. Overreliance on the internet and smartphones have aspects of withdrawal and tolerance, which could bring impairment to daily life (National Information Society Agency, 2015). A survey by the Ministry of Gender Equality and Family on the use of the internet and smartphones (2020) showed that the risk of overdependence among elementary school students increased by $16.7 \%$ compared to the previous year (Gumgang Ilbo, 2021). As such, there are raising concerns about children's overdependence on the internet and smartphones.

Naturally, most of the outdoor group activities, such as tagging and soccer, and even board game and choir activities that often took place in elementary schools have been suspended due to classes being conducted online (Yonhap News, 2020). Children had insufficient play time even before the pandemic, and now that time has reduced even further. Most children today live a lifestyle that is an outcome of an urban-centric culture; most of their homes have neither a yard nor a garden. Their lives are focused on the academics, going straight to after-school academies once school classes are over. Then they spend the remaining time of the day on the internet or their smartphones. Their play time consists of watching digital comics, surfing the internet, playing digital games, and engaging in social media (Kweon, 2018).

Children from underprivileged families or double-income families receive insufficient parental care and spend a lot of time alone (Chung, Lee \& Kang, 2020). The longer children spend time alone, the more they use the internet and smartphones, leading to a higher probability of overreliance. For these children, the local child centers function as an extra complementary system between home and school (Back, 2016). With a growing gap in childcare due to the COVID-19 pandemic, the government is implementing various policies for children from 
Park, Sung Min · Jo, Yun · Jung. Hyun Kyoung / An Arts-based research on group sandplay therapy for children in local children's centers who are overly dependent on internet and smartphones experiencing the COVID-19 pandemic era

vulnerable families, including expanding the hours of local child centers. Nevertheless, children receiving care at such centers are forced to spend time alone when schools are closed due to the pandemic, and therefore they feel dissatisfaction stemming from lack of interpersonal relationships and are prone to feeling loneliness, which one often feels when failing to belong to a social group (Im \& Shin, 2020). As a matter of fact, children's use of media increased during the period of not physically attending schools (Yonhap News, 2020), which is in sync with the study findings that loneliness caused by the lack of social and emotional relationships can raise the possibility of smartphone addiction (Kim, 2017). Increased time spent alone by children being taken care of local child centers and the trauma that stems from relational disconnections can increase negative emotions such as depression, anxiety, aggression and impulsivity (Sohn, Choi \& Kong, 2016).

This study sought to provide psychological treatment, i.e., sandplay therapy, to become aware of and intervene in the emotional difficulties of children who are overly dependent on the internet and smartphones. To be specific, therapy was given to those children receiving care at local child centers. Children tend to express their negative experiences, fear, sadness, and agony though play rather than verbal expressions. To gain a better understanding of the situational difficulties that caused internet and smartphone overdependence among children and the psychological responses as well as resulting emotional difficulties, therefore, a play approach is appropriate (Jang, 2018).

The play activity mentioned in this study is a creative activity that connects imagination to activities in sand, contrary to play activities on the internet and smartphones. Visual plays, i.e., playing games and watching video, on the phone are static, isolated plays. They prevent children from engaging with other children and isolate them from relationships (Lee et al., 2015). Such type of play does not stimulate children's imagination. Pre-created images claim imagination from children and make them passive (Erickson, 1991/2008). Gaston Bachelard, a philosopher who emphasized the importance of images and imagination, said imagination is the ability to not only induce reproductive images but also create new images (as cited in Hong, 2005).

Children's play is a byproduct of imaginations, and it is similar to the creative work of an artist. Susanne Langer, a philosopher of art, called imagination an inherent trait of mankind that is older than inferred reason. When young children engage in play, they pour in their energy of 
Journal of Symbols \& Sandplay Therapy, Vol.12 No.1.

curiosity and show determination to create something. Consequentially, they present their own creations. In principle, this process is no different from that of artists like Picasso. In the end, the impulse to create something is the same (Erickson, 1991/2008).

The same goes for literary art. Robert Louis Stevenson, author of The Strange Case of Dr. Jekyll and Mr. Hyde, woke up one morning and was inspired by last night's dream to complete the novel in a heartbeat. It was not planned or anticipated, like play. Stevenson completed the novel in just a few days, led by imaginations and fantasies that came from deep inside. Unless disturbed, children immerse themselves in play. One of the key elements of the play is the spontaneous imaginations and fantasies. In other words, the impulse for creation in art and play are deeply connected.

In explaining art, the German philosopher Friedrich Nietzsche compared it to children's play. Children's play signifies artistic impulses, and every human being becomes an artist. All human beings play and, in this regard, all human beings are artists and the act of art is represented in the form of play. All creation activities can be called art, which includes both the conscious and unconscious activities of man (Jeong, 2012). Therefore, providing children with opportunities for creative play, which allows the realization of their spontaneous imaginations, is highly important. Such opportunities enable them to manifest or realize their imaginations as well as artistic impulses. Winnicott also mentioned that the key element of play is creativity, and that spontaneous play is important. Play has intrinsic value and is vividly alive; it is inherent in art, which is part of the human life (Caldwell \& Joyce, 2011/2015).

According to Jung, creative acts in art come from the unconscious (Jung, 1990/2015). Imagination, which naturally arises from the unconscious, is created to inform the conscious of something of the unconscious and is expressed as images (Jung, 1985/2004; Jang, 2018). The realization of imagination and play-artistic impulses play a crucial role in the recovery of our wholeness. By understanding all human actions as artistic, play, as a form of art, is the beginning of creativity and contains important elements of art (Nachmanovitch, 1990/2008). In other words, play includes artistic impulses and acts of creation, which is inherent.

There is a linguistic concept that implies play is linked to creative behavior. An old Sanskrit word, lila, means play. More specifically, it means divine play, the play of creation, destruction, and recreation (Nachmanovitch, 1990/2008, p.17). As such, play is archetypal and 
Park, Sung Min - Jo, Yun · Jung. Hyun Kyoung / An Arts-based research on group sandplay therapy for children in local children's centers who are overly dependent on internet and smartphones experiencing the COVID-19 pandemic era

intrinsic. It allows access to the nature to the deep unconscious, therefore bringing healing to conflicts in ego-consciousness and gearing life towards a creative direction (Jang, 2017). However, children in modern society are losing opportunities to be in contact with the unconscious, e.g., instinct (Kast, 1992). Unlike other animals, man cannot be satisfied just by having their basic needs for survival satiated (Jeong, 2017). Thus, opportunities for play should be given sufficiently. In this regard, play is closely related to the nature of children and can be said to be an archetypal impulse.

Jung claimed that human beings are innately born with archetypes, and that archetypes are a psychic structure that is transmitted through the genes (Jung, 2014; as cited in Jang, \& Lee, 2020). When the archetypal energy is manifested in the human psyche, the purposiveness of the ego-consciousness weakens, ego-consciousness like time and numbers become reduced, spontaneity overrides planning, strong emotional pull and spontaneity are experienced, and the desire to continue that experience develops. At this point, the manifestation of archetypal energy takes the form of an imagination or fantasy. When connecting art to play, this is why many artists spend time in silence, waiting for inspiration to come to their mind. Winnicott explained that creative impulse is needed for not only artists to produce a work of art but also anyone (1991/1997). Just as the state of concentration that appears in play, the state of immersion where intrusion is not tolerated easily is needed. They need the opportunity to freely express their creative impulse.

Jung said that the power of the unconscious takes place in art or in the cultural realm expressed by man; in other words, in all creative work. The unconscious intuitively identifies unknown properties and process them archetypally. The archetype has its own energy. Because archetypes have autonomy (Jung, 1996/2007), they naturally come into contact with our nature and unconscious aspects. The archetype is an image of the impulse, and a psychic goal that the human nature is oriented towards psychologically (Jung, 1984/2002, p.78). Thus, children's expressing artistic impulses and engaging in acts of creation is the unconscious expression of their nature, and it often leads to healing and transformation. This is not only true of play but also of art. While the initial goal of the artist or the work of art itself is not to heal, healing and transformation occur in the process of creation. The archetypal, unconscious power contained in the imagination and fantasy leads to act of creation. 
Journal of Symbols \& Sandplay Therapy, Vol.12 No.1.

Jung applied a technique called "active imagination" to his clients. Through active imagination, the clients engaged in meditation and attempted to connect with their unconscious, trying to heal their psyche while being consciously connected to their inner phenomena (Jung, 1996/2007). In other words, one can discover the messages of the unconscious through active imagination. Archetypes appear as images and are dynamic and divine. Jung said that dreams, or imaginary forms of thinking, can be worked naturally by unconscious motives. This unconscious work involves the instinctive aspect of our psyche and is represented by symbols (Jung, 1984/2002).

The researchers of this study thought that administering sandplay therapy, which involves the use of imagination and symbols, to children would help them heal. The researchers are aware of how COVID-19 has deprived children of the opportunity for play and aggravated children's reliance on internet and smartphones. Creative play, which well represents children's unconsciousness, through instinct and imagination can bring healing, just like the healing attributes of art (Jang, 2018). All of the explanations above are based on the premise that the hypothesized healing brought about by sandplay therapy is supported by the innate healing power of the human psyche. The innate healing power of the human psyche is expressed as images through creative imaginations in fantasies, sandplay and other expressive arts and is projected onto symbols (Jang, 2017).

Sandplay therapy is a psychotherapeutic approach that projects the unconscious, or imaginations or fantasy images in the inner world, into the sand tray, sand, and figures and helps understand their meaning. Imagination, which originates from the unconscious, is the driving force of active change that constantly renews life as well as the source of creation. Jung focused on imagination because of its creative, healing, transformative attributes. Imagination does not merely reproduce the images that are emerged. Through these images, we are able to gain an understanding of the depts beyond the images, i.e., we are able to understand what the conscious has not been aware of (Kim, 2017, Jung, 1990/2015). Hence in sandplay, the unconscious can talk instead of rational thinking. The means of communication of the unconscious involves not only verbal but also nonverbal means. Through sandplay that allows nonverbal expressions, deep inner experiences of the client can be symbolically expressed and 
Park, Sung Min · Jo, Yun · Jung. Hyun Kyoung / An Arts-based research on group sandplay therapy for children in local children's centers who are overly dependent on internet and smartphones experiencing the COVID-19 pandemic era

conveyed (Boik \& Goodwin, 2000/2012). While the sandplay therapy process does involve verbal conversations, self-expression through actions and behaviors becomes the major source of communication and hence sandplay is defined as a nonverbal approach. Because children do not always speak accurately of their emotions and experiences (Malchiod \& Crenshaw, 2013/2019), nonverbal means of communication are an important part of the therapy.

It would be meaningful to administer group sandplay therapy to children who experienced relational disconnection and reduced opportunities for play due to COVID-9 so as to enable them to express their feelings through play and interact with one another. And the receptive attitude of the therapist will be effective in bringing recovery to their relationships and healing to their psychological difficulties. Under this belief, the researchers of this study decided to provide group sandplay therapy to children at local child centers who rely on the internet and smartphones. It is difficult for children to control their use of the internet and smartphones on their own, even if they want to. Therefore, it is necessary to provide an opportunity to listen to their stories and play together in a group setting, in a natural manner.

The advantage of a group sandplay therapy is that the creative energy naturally forms an empathetic setting, in which the participants would be able to share their difficulties through nonverbal communication and realize that the problems and emotions they are experiencing are not just of their own, thereby receiving comfort (Jeon, 2019).

One of the key elements of sandplay therapy is the receptive attitude of the therapist, who come to understand the process through the method of intersubjectivity, which involves the imagination on the part of the therapist. In analytical psychology, this is sometimes called an “intuition." During sandplay process, clients unconsciously choose figures and spontaneously create a sandpicture. Only later do they come to understand the meaning of the sandpicture and about themselves in a conscious manner (Jang, 2017). With regards to this intersubjectivity, analytical sandplay therapist Ravitz said that therapists ought to "listen" to what their body feels during imaginative play, art and sandplay therapy, and also pay attention to nonverbal behaviors, attitudes, emotions and images that are revealed during therapy. Such an attitude allows the therapist to connect intuitively with the client and to understand the client's psyche at a deeper level (Audrey, 2018). 
Journal of Symbols \& Sandplay Therapy, Vol.12 No.1.

To understand and study the client's psyche, which is expressed through nonverbal means and imaginations in sandplay therapy, at a deeper level, qualification of data and statistical methods to determine causal relationships, as is the case in quantitative studies, have their limits (Barone \& Eisner, 2012). Therefore, to better examine both verbal and nonverbal expressions taking place in sandplay therapy, the method of art-based research (ABR) was applied, which emphasizes the researcher's intuition and symbolic, metaphorical thinking skills (Leavy, 2015/2018). ABR practices are methodological tools used by researchers across the disciplines during any or all phases of research, including problem generation, data or content generation, analysis, interpretation, and representation. Theories and practices are connected. These tools adapt the tenets of the creative arts in order to address research questions in a holistic and engaging way. This process of inquiry therefore involves researchers engaging in art (Leavy, 2015/2018). The use of $A B R$ in art therapy is useful in conveying the unique functions, roles and experiences of art (So, 2020). The presumption is that art can create and deliver meaning (Barone \& Eisner, 2012). ABR also provides insights through a variety of explanations, discoveries, and problem-solving methods. The aim of applying ABR practices is to create an expressive form that will enable an individual to secure an empathetic participation in the lives of others and in the situation studied (Susan \& Joel, 2021).

This study seeks to add the viewpoint of Jungian psychology to the existing art-based research so as to bring the knowledge that is gained through it; It is to bring the unconscious, or the messages of the psyche, to consciousness. Nevertheless, it can be assumed that what is ultimately learned is the same. Due to the outbreak of COVID-19, children at local child centers experience a long time spent alone during the day, with the parents or other guardians absent; lack of social relationships; and over-reliance on the internet and smartphones. Sandplay therapy was administered to these children to give them an opportunity for play and mitigate their psychological difficulties, which may possibly reduce their reliance on their internet and smartphones. The entire sandplay process, including the symbols that are expressed, will be examined through the lens of analytical psychology. 
Park, Sung Min · Jo, Yun · Jung. Hyun Kyoung / An Arts-based research on group sandplay therapy for children in local children's centers who are overly dependent on internet and smartphones experiencing the COVID-19 pandemic era

\section{ПI. RESEARCH METHOD}

\section{A. Art-Based Research}

Since the advent of social science research, the perspectives and methodologies of research have constantly changed. Positivism, an early social science paradigm for quantitative research, holds that a knowable reality exists independently of the research process, and this reality consists of knowable "truth," which can be discovered and measured via objective means employed by neutral researchers (Leavy, 2015/2018). And to supplement the limitations of quantitative research having positivist and dualistic attributes, an alternative paradigm called qualitative research arose. This new paradigm seeks to understand the phenomenon based on the meaning and interpretation given by individuals within unmanipulated natural situations (Kang, 2009). However, qualitative research is also evaluated based on the values of quantitative research: turning recoded data into codes, link them as categories, and thus providing logic, system and association. (Lee, 2017). So as a complementary paradigm, a new shift in thinking called art-based research was created (Finley, 2003).

ABR is a method of research that uses one or more artfully-expressed forms, such as images, sound patterns of music, dynamic dance, or literature or poetry in linguistic forms, that are discovered in painting, sculpture, film and video as a means of communication (Eisner, 1993). By introducing art to the way research problems are presented, the likelihood that the scope and purpose of the research will be presented in board, open text opens up readers' thinking and provides motivation for approaching the problem (Lee, 2017). ABR blurs the boundaries of qualitative research expressions, which relied primarily on existing languages, and diversifies the way experiences are confronted and represented (Barone \& Eisner, 1997).

Art delivers immediately and empathically and thus is very effective in conveying the knowledge of the emotional aspect (Leavy, 2019). Artistic experiences enable people to see and think differently and feel at a deeper level, thus allowing them to gain a mutual and in-depth empathy and intuitive understanding (Beer, 2016). By materializing and expanding what we wish to know through empathy and understanding (Leavy, 2015/2018), ABR can fully communicate and engage readers with the new perspectives it presents. 
Journal of Symbols \& Sandplay Therapy, Vol.12 No.1.

ABR breaks down boundaries between researchers, research participants, and readers, and aims to expand the responses, perceptions and empathy of everyone who conducts and encounters the research (Park, 2020). Therefore, "art" in ABR is not limited to professional art or works of professional artists (Susan \& Joel, 2021). Those that express human artistic sensibility and human nature are included in the realm of creative art in a broad sense, regardless of materials and techniques used. Thus, the comprehensive and creative art form allows the world to be vividly captured and make experiences that are uncertain or in-definitive more accessible. So when children play with creativity and imagination, as one would do in art, they provide consciousness and insight that allows the "observer" to gain a better understanding of what is going on (Eisner, 1995). In this respect, the method of ABR is suitable for this study.

In this sense, $\mathrm{ABR}$ already exists in Jungian psychology. In Jungian psychology, the presence of the unconsciousness represents the unknown incompleteness, and through the psyche, which is the inherent drive toward wholeness of the personality, seeks to connect what is known to unknown (Susan \& Joel, 2021). In other words, the cope of consciousness is widened by making the unconscious conscious. Psyche, in Jungian psychology, always yields images in the form that is consciously comprehensible. These images are projected onto symbols, allowing indirect understanding of the intentions and impact of the unconscious (Jang, 2017). In this process of understanding symbols, images of the imagination and elements of impulse are experienced (Stein, 2015). Since images are ultimately based on imagination and fantasy and art begins from imagination and fantasy, play is also a creative art in a broad sense (Jang \& Lee, 2020). In Jungian psychology, being ignorant of unconscious knowledge leads the conscious and its center, the ego, to suffer from psychological problems. Therefore, psychotherapy such as sandplay therapy uses a creative art method called "sandplay" to listen to the voice of the unconscious and, as a result, seeks to expand the personality and bring healing.

It is based on these assumptions and theoretical paradigms that the method of Jungian art-based research was applied in this study. The value of this study lies in the fact that it explores unique artistic experiences, which cannot be delivered through existing research methods, to understand the truth of the unknown and expand awareness (Barone \& Eisner, 2012), which is expected to bring psychological healing to children. 
Park, Sung Min · Jo, Yun · Jung. Hyun Kyoung / An Arts-based research on group sandplay therapy for children in local children's centers who are overly dependent on internet and smartphones experiencing the COVID-19 pandemic era

\section{B. Research Participants}

This study selected research participants by administering the internet Addiction Proneness Scale for Youth (K-scale), created by the National Information Society Agency, to children aged 10 to 13 at local child centers in Gyeonggi province. The K-Scale is structured around four factors - disruption in daily life (5 items), virtual life orientation (2 items), withdrawal (4 items), and tolerance ( 4 items) - and scores are based on a 4-point Likert scale. The scores range from 15 to 60 , with high scores representing high severity of internet addiction. Those in the high-risk group are have a total score of 30 or more, or 14 for disruption in daily life, 12 for withdrawal, and 11 for tolerance. Those in the potential risk group have a total score of 28-29 or 13 for disruption in daily life, 11 for withdrawal, and 10 for tolerance. Others are classified as ordinary user groups. Children who were classified as being in the high-risk group according to the K-scale were selected to take part in the research: six in grades 5 and 6 (3 boys and 3 girls) and 5 in grades 3 and 4 (2 boys and 3 girls). General information of the participants is outlined in Table 1.

\section{Research Procedure}

Prior to starting group sandplay therapy, an explanation of the research objective and process was provided to the participants, their guardians, and the chief and the social workers at the local child centers and received a written consent. The participants were divided into two group: one group with children in grades 5 and 6 and other with those in grades 3 and 4 . Therapy was administered consecutively, first on the grades 5 and 6 group and then the grades 4 and 4 group. A total of 6 sessions were given, each 90 minutes long, from July 15 to November 18, 2020. During this period, the participants went to school only once or twice a week or did not go to school at all depending on the number of COVID-19 confirmed cases in the country. When social distancing was raised to level 2, the therapy was suspended temporarily and resumed when the situation mitigated.

Sandplay therapy was conducted in a non-directed way so as to provide a "free and protected space" suggested by Dora Kalff (1980). Each participant created individual sandpicture. 
Journal of Symbols \& Sandplay Therapy, Vol.12 No.1.

Table 1. General Information of Research Participants

\begin{tabular}{|c|c|c|c|c|c|}
\hline Participant & Sex & Age & $\begin{array}{l}\text { internet Addiction Proneness } \\
\text { Scale for Youth (K-scale) }\end{array}$ & Family relationship and attributes & Chief complaint \\
\hline Child A & $\mathrm{F}$ & 10 & 32 (High-risk group) & Lives with both parents. & $\begin{array}{l}\text { Difficulty in controlling time } \\
\text { spent on a smartphone. }\end{array}$ \\
\hline Child B & $\mathrm{F}$ & 10 & 32 (High-risk group) & $\begin{array}{l}\text { Parents divorced. Lives with } \\
\text { mother and older sister. }\end{array}$ & $\begin{array}{l}\text { Difficulty in controlling } \\
\text { emotions. Often irritated. }\end{array}$ \\
\hline Child C & $\mathrm{F}$ & 10 & 31 (High-risk group) & $\begin{array}{l}\text { Lives with parents. Both parents } \\
\text { work and come home late. }\end{array}$ & $\begin{array}{l}\text { Spends a lot of time alone or } \\
\text { with her older brother only as } \\
\text { parents come home late. }\end{array}$ \\
\hline Child D & $\mathrm{M}$ & 10 & 32 (High-risk group) & $\begin{array}{l}\text { Lives with grandmother, uncle, and } \\
\text { older brother. Mother neglected the } \\
\text { child due to severe depression. }\end{array}$ & Impulsive and distracted. \\
\hline Child E & $\mathrm{M}$ & 10 & 45 (High-risk group) & $\begin{array}{l}\text { Lives with parents and younger } \\
\text { sibling. Parents have hearing } \\
\text { impairment. }\end{array}$ & $\begin{array}{l}\text { Distracted. Talks a lot to } \\
\text { attract other people's attention. }\end{array}$ \\
\hline Child F & $\mathrm{F}$ & 12 & 52 (High-risk group) & $\begin{array}{l}\text { After parents' divorce, was separated } \\
\text { from parents and spent a year at a } \\
\text { childcare institution. }\end{array}$ & $\begin{array}{l}\text { Often in conflict with teachers at } \\
\text { the school and the child center. } \\
\text { Finds it difficult to follow the } \\
\text { rules. }\end{array}$ \\
\hline Child G & $\mathrm{F}$ & 13 & 30 (High-risk group) & $\begin{array}{l}\text { Absence of father. Mother is sick } \\
\text { and often admitted to the hospital. } \\
\text { Thus, the child spends most of her } \\
\text { time with older sister. Barely } \\
\text { interacts with her older sister. }\end{array}$ & $\begin{array}{l}\text { Often spends time alone. } \\
\text { Often expresses feelings of } \\
\text { depression. }\end{array}$ \\
\hline Child $\mathrm{H}$ & $\mathrm{F}$ & 13 & 34 (High-risk group) & $\begin{array}{l}\text { Parents come home late and thus } \\
\text { the child spends a lot of time } \\
\text { alone. }\end{array}$ & Appears physically withdrawn. \\
\hline Child I & $\mathrm{M}$ & 13 & 35 (High-risk group) & $\begin{array}{l}\text { Lives with parents and younger } \\
\text { sister. Parents fight often. The } \\
\text { father is alcoholic and abusive. The } \\
\text { mother is depressed. }\end{array}$ & $\begin{array}{l}\text { Impulsive and distracted. } \\
\text { Trouble in peer relationship. }\end{array}$ \\
\hline Child J & $\mathrm{M}$ & 13 & 34 (High-risk group) & $\begin{array}{l}\text { Absence of father. Mother's neglect. } \\
\text { Currently lives with grandmother, } \\
\text { maternal uncle, and younger sibling. }\end{array}$ & $\begin{array}{l}\text { Difficulty in controlling } \\
\text { emotions. Does not follow } \\
\text { group rules and therefore often } \\
\text { is in conflict with teachers. }\end{array}$ \\
\hline Child K & $\mathrm{M}$ & 13 & 39 (High-risk group) & $\begin{array}{l}\text { Lives with parents. Both parents } \\
\text { work and come home late. }\end{array}$ & $\begin{array}{l}\text { Often spends time alone } \\
\text { at home. Cannot get along } \\
\text { with friends. }\end{array}$ \\
\hline
\end{tabular}


Park, Sung Min - Jo, Yun · Jung. Hyun Kyoung / An Arts-based research on group sandplay therapy for children in local children's centers who are overly dependent on internet and smartphones experiencing the COVID-19 pandemic era

While conducting group sandplay therapy, the researches decided that meeting the guardians was of a necessity. Therefore, a 90-minute, face-to-face meeting was held with the chief of the local children's center, the competent social workers who take care of the participants, and the guardians with respect to the grades 5 and 6 group. A face-to-face meeting was not a possible option for the grades 3 and 4 group, as the pandemic situation was getting severe at the time they received therapy. Therefore, individual education and meeting was held via telephone.

After each session, the researchers shared and recorded materials related to the children, the sandpictures, imaginary stories told by children, behaviors displayed by the children, and thoughts, emotions and feelings that came to the researchers when they were with the children. The same was done when the entire therapeutic process was over. The aim was to understand the sandplay process through the lens of intersubjectivity.

\section{Data Collection and Analysis}

Among various forms of art-based research, the method adopted in this study was creative art: sandplay therapy. Sandpictures representing participants' imaginations, imagined stories related to the sandpictures, imaginations evoked in the researchers, and feelings of intersubjectivity were the main data. For an integrated understanding of the meaning of sandpictures, children's history and background information, observational records of the children including nonverbal behaviors, transcript of statements made by the participants, and records of meetings with guardians and social workers were collected.

A total of 56 individual sandpictures, imaginary stories about the pictures, and comprehensive information about children all collected during group sandplay therapy were analyzed from the viewpoint of analytical psychological. After the analysis, meaningful information was recorded, and common topics were categorized and specified.

\section{E. Research Integrity}

To ensure integrity and validity in ABR, McNiff (McNiff, 1988, as cited in Park, 2020) suggested that a team be formed to explore the research amongst the team members. The 
Journal of Symbols \& Sandplay Therapy, Vol.12 No.1.

members of the team would be the co-researchers. He proposed a team with two or more participants in conducting $\mathrm{ABR}$ on the following grounds: First, the diverse dynamics and creativity provided by the group can deepen the knowing of the research topic. Second, the opinions of those who conduct the study together can be the most important indicator of the validity of $\mathrm{ABR}$. This statement is related to the use of triangulation. The research can be explained, interpreted and evaluated through an agreed validation of the co-researcher; the other's validation can support the research (Eisner, 2005).

This study was conducted jointly by three doctoral students majoring in child counseling and psychotherapy. Among them, the one who actually administered group sandplay therapy has studied child counseling and psychotherapy in both her master's and PhD programs. She took part in workshops and supervisions via the Korean Society of Sandplay Therapy (KSST) and attended multiple conferences for many years. She obtained sandplay therapist level one certificate from KSST, and has more than 10 years of clinical experience in child counseling, which includes individual play therapy, sandplay therapy, and group counseling. The researchers of this study recognize the importance of play for children and have received training for analyzing and finding meaning in children's sandplay process.

For intersubjectivity, the researchers held sessions for in-depth observation and discussion during and after therapy, once a week. In addition, the method of triangulation was used through continuous talks among the researchers-in relation to face-to-face meetings, observed behaviors, thoughts and feelings of the researchers, the sandpictures, and the stories told - for integrity and validity of the research findings. The outcome was examined by a professor specializing in sandplay therapy, who made necessary modifications and supplementations. In terms of interpretation, provided advice from analytical psychological sandplay therapy specialists to allow for more in-depth interpretation and analysis.

\section{RESEARCH FINDINGS}

Participating children with overdependency on the internet and smartphones who are living through the COVID-19 pandemic created sandpictures from imagination and talked about the 
Park, Sung Min · Jo, Yun · Jung. Hyun Kyoung / An Arts-based research on group sandplay therapy for children in local children's centers who are overly dependent on internet and smartphones experiencing the COVID-19 pandemic era

scenes they imagined and created. Images that appear in sandpictures become the raw material of art, and art images become the tools for communication among individuals and groups (Susan \& Joel, 2021).

The sandpictures and stories created from imagination by the children were categorized into four common themes, listed in Table 2 .

Table 2. Common Themes and Details of Sandpictures and Imagined Stories

\begin{tabular}{|c|c|}
\hline Theme & Details \\
\hline Seeking affection & $\begin{array}{l}\text { Craving for food, a mother with her baby, pursuing popularity on social media, } \\
\text { animals understanding human minds and caring for them, seeking to make } \\
\text { friends. Seeking communication with someone. }\end{array}$ \\
\hline Suffering from anxiety & $\begin{array}{l}\text { A volcano that may erupt at any moment, sudden car or airplane accident, } \\
\text { attacking monster, being lost, destruction of the world. }\end{array}$ \\
\hline $\begin{array}{l}\text { Coping with loneliness } \\
\text { and lack of communication }\end{array}$ & $\begin{array}{l}\text { A deserted island, a desert, living alone in an empty place, a smartphone used in } \\
\text { isolation, a person using a laptop computer with no communication with others, } \\
\text { people drinking alcohol. }\end{array}$ \\
\hline Striving to protect oneself & $\begin{array}{l}\text { Trying to protect animals in danger of death, getting revenge on people who } \\
\text { killed one's family, protecting abandoned animals, fighting over food, leaving } \\
\text { home for a place of stability, protecting a house against invaders. }\end{array}$ \\
\hline
\end{tabular}

\section{A. Seeking Affection}

\section{Scene from imagination}

In the middle of the sandpicture, a baby is drinking alcohol on top of a toilet. Animals are surrounding the baby, each with a different type of food placed before them. The animals are also drinking alcohol in directions different from the baby. A red lobster and tiger are drinking on the baby's left side, and they are relatively larger than the other animals.

\section{Story from imagination}

"Outsiders drink because they are lonely. They want to become insiders. Outsiders are kids who are left out from groups. These are friends. The baby is two months old. The parents do not love 


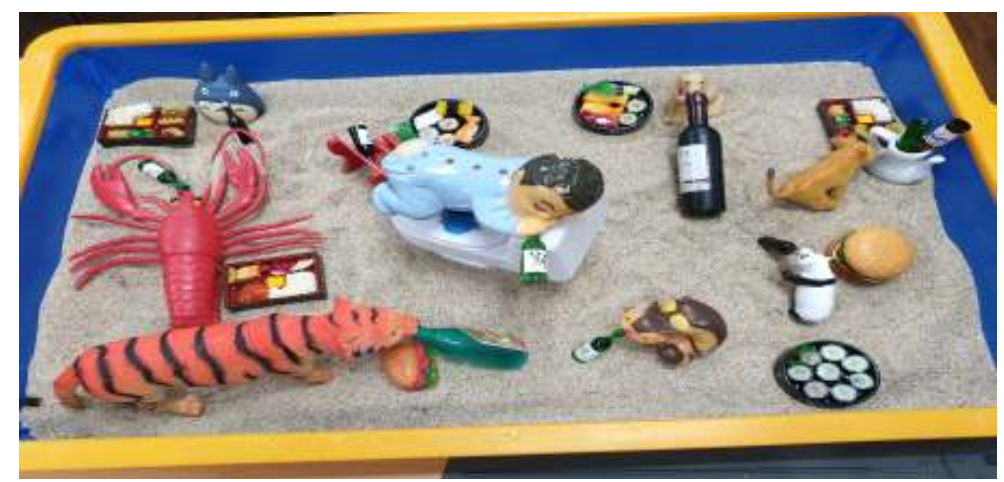

Fig 1. Sandpicture created by Child I in Session 1

the baby. This is what the baby is wearing. The baby is drinking on the toilet because he wanted to poop but found soju there. Although not seen here, there is a reporter in the corner. The reporter takes pictures and shares them on Instagram. They become insiders on social media. Here, they are depressed, but they strive to become insiders."

Child I, who created the sandpicture in Figure 1, lives with a father who has symptoms of alcohol addiction and a mother who has been depressed for a long time. According to the mother, the father has been going through a stressful time due to economic hardships caused by COVID-19. She said that he would drink and show violent behavior toward family members, which aggravated tensions between the two parents. Child I has recently been using his smartphone much more often and was getting harder to control, leading to more frequent conflicts between mother and son.

In his story, Child I mentioned that loneliness leads to drinking and that nobody cares for the baby. The sandpicture and story that Child I created include food figures that symbolize a deficiency of affection and the mother (Kalff, 1980). The researchers sensed the extreme loneliness of Child I, the lack of care, and his yearning for affection. In his story, Child I strived to become an insider to break out of loneliness and depressing circumstances. The fact that he was struggling to become an insider in the world of social media, where most modern-day children participate, suggests that the child wants to communicate with people and receive their affection and attention rather than staying home alone. Such desires were plainly displayed. 
Park, Sung Min - Jo, Yun · Jung. Hyun Kyoung / An Arts-based research on group sandplay therapy for children in local children's centers who are overly dependent on internet and smartphones experiencing the COVID-19 pandemic era

The researchers felt overwhelmed when they saw the red lobster and tiger in the sandpicture, which were larger than other animals. The various figures of food items and animals were mixed with alcohol figures, which led to a question about what alcohol means to Child I. His father's alcoholism is an environmental factor inseparable from the child's everyday life. It seemed that Child I used the enormous red lobster and tiger to express the conflicts between his mother and father that began when he was younger, caused by his father's drinking habits and violent behavior. The baby is placed next to the huge and possibly threatening lobster and tiger, which may be dangerous. This may be an indication of emotional anxiety that Child I experiences at home.

The researchers took note of Child I talking of friends who are outsiders and left out from peer groups, and the baby figure placed at the center of the sandpicture. The researchers were able to understand the situation that Child $\mathrm{I}$ is placed in. Living in a painful reality, the child's parents probably do not have the psychological or material means to provide sufficient affection to Child I. In return, Child I had to grow up without being sufficiently loved by his parents and thus is suffering from a lack of affection. The researchers suspect that Child I's father is drinking to flee from the psychological pains that come from difficult life circumstances, negative emotions and reality. In the same vein, Child I may be immersed in his smartphone to avoid facing unstable emotions and difficulties in peer relationships with ensuing emotions. It seems that in reality, Child I is looking for someone who loves him and can calm his anxiety.

Due to his obsession with smartphone games, Child I often arrived late at the local children's center and clashed with the social welfare worker in charge. Although Child I had a desire to form relationships, the impression was that he had trouble belonging in groups and was excluded due to his inability to interact emotionally with his peers, as expressed in the sandpicture. This may be the reason behind his obsession with relationships in the virtual world of smartphone games, making it more difficult for him to belong in real-life groups. Child I did not open his heart to the researcher during the earlier sessions and outrightly stated that the activity was boring, showing signs of difficulty in belonging in groups. However, as the sessions went on, Child I started to focus and expressed and talked about his sandpictures. He also began to have friendly conversations with other children and interacted with them by creating 
Journal of Symbols \& Sandplay Therapy, Vol.12 No.1.

sandpictures together. Towards the end of the sessions, Child I tried to catch the researcher's attention by hiding under a desk. When the sessions were over, he said that he wanted to do it again. The social welfare worker in charge reported that Child I seemed to feel a sense of belonging and that he was much better at following the rules at the local children's center, which led to fewer disagreements with social welfare workers. The social welfare worker also shared that after consultations with his caregivers, Child I was introduced to an individual counseling program to continue to receive individualized counseling.

\section{B. Suffering from Anxiety}

\section{Scene from imagination}

Some cars have flipped over, some are on their sides, and some are on top of one another. They are placed in an irregular and disorderly manner in the sandpicture. The cars take up only one side of the sandpicture, leaving the other side empty. A few cars are buried under the sand.

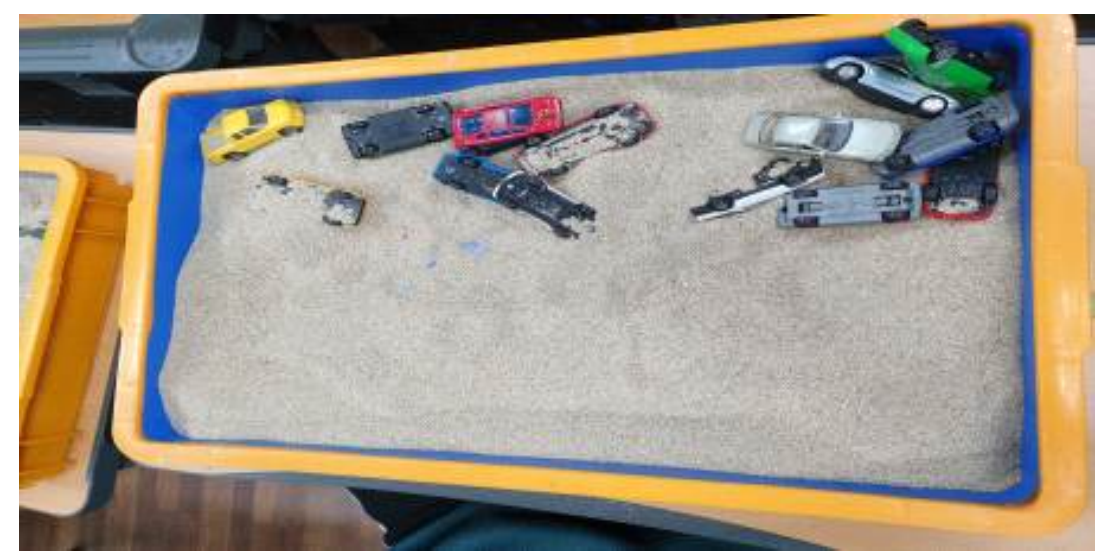

Fig 2. Sandpicture created by Child D in Session 2

\section{Story from imagination}

"I created a motorway. The cars are heading for the grave. It is a junkyard. The cars must be 
Park, Sung Min · Jo, Yun · Jung. Hyun Kyoung / An Arts-based research on group sandplay therapy for children in local children's centers who are overly dependent on internet and smartphones experiencing the COVID-19 pandemic era

buried. They are now useless. This is where the souls of the cars reside. They are trying to take revenge against the junkyard owner. The cars didn't want to die, and now they want to kill and take revenge on the owner. The souls of these cars want to kill. They will stab people and kill them. They will also kill innocent people because they are angry. Once the cars get their revenge, their souls are released. They turn the people they killed into dust. The dust goes up to the sky and disappears. The souls become evil spirits and they also die. I love it. The cars are buried under the sand. They should not be seen (covers cars with sand). I must be a psychopath for sure. I sometimes feel the urge to kill someone. I play a lot of games with killing in them."

Child D, who created the sandpicture in Figure 2, was abused by his mother in the form of neglect. Child D said that he does not live with his mother now because she did not give him his meals.

Cars were not the original theme of the sandpicture. At first, Child D created a house that had furniture and hamburgers. As he was pondering on his work, he suddenly got up as if something came to his mind and brought back volcanoes that looked like they were about to erupt. At that moment, something about Child D's facial expression changed. It reflected anger and anxiety. The volcano figures may have triggered courage to face the negative feelings of anger and anxiety that have been trapped inside the unconscious. Then suddenly, Child D took out all of the volcanoes and started to place cars in the sand tray. It seemed that the complex, negative feelings that exist in the inner world of Child D were connecting his dynamically changing feelings with the destruction of volcanoes and the image of disorderly cars. The depiction of uncontrollable and unpredictable car accidents may be an expression of Child D's uncontrollable anxiety.

Child D mentioned that the cars are now useless. The researchers contemplated on the possibility that his story was reflecting anger and a feeling that his existence had no value, caused by parental neglect. One researcher thought about Child D's feelings, who perceives himself as a useless, rather than a beloved, existence to his parents. It seemed that the anxiety of being unsafe was connected to anger and that the oppressed anger in Child D's inner world was expressed in the form of revenge against the junkyard owner. The feeling of being rejected seemed to have developed into anger.

Since he was very young, Child D was often hospitalized for pneumonia. His caregivers 
Journal of Symbols \& Sandplay Therapy, Vol.12 No.1.

were his grandmother, who had trouble moving around, and his uncle, who was the breadwinner of the family. Because they were living in such dire circumstances, the caregivers could not provide proper emotional or physical support even when Child D was in the hospital. Child D stated that the thing he did most during hospital stays was use his smartphone. We assume that Child D would have felt very lonely in the unfamiliar hospital environment. Child D was left alone, all by himself at the hospital, and the only thing that was beside him was his smartphone. Even after he was discharged, his usage of the smartphone continued to increase. His excessive smartphone use may have caused difficulty in controlling aggressive impulses, leading him to physically hurt other children.

According to a report by a social welfare worker, Child D was often scolded at school and the local children's center for his aggressive behavior because he would hit his friends when he was angry. At the following sandplay therapy session, Child D arrived angry because he had just been reprimanded by his teacher regarding a book report. He was emotionally agitated as he spoke and had trouble concentrating on what the researcher was saying. However, once the sand tray was placed in front of him and he started to play with the sand, he was immersed and silent. As he watched the sand slowly slipping through his fingers, he told the researcher, "It seems like time is slipping down, just like a sandglass," and that "it feels as if my anger is slipping down, and I feel better." He then looked at the sand and smiled. As the sessions progressed, it became increasingly apparent that Child D's feelings were naturally turning stable during sandplay. Child D has a loud voice and is easily aroused, and often ends up physically hurting other children. However, when other research participants or researchers were listening to him, he spoke slowly with good eye contact and seemed more emotionally stable.

\section{Coping with Loneliness and Lack of Communication}

\section{Scene from imagination}

The child is lying on her own. Everything around her is quiet and there are no other people. There are blue beads in a container that can hold things, and alcohol in a figure that looks like a mortar. There is a smartphone and computer at the feet of the child. The airplane hangs a little to the side of the structure. 


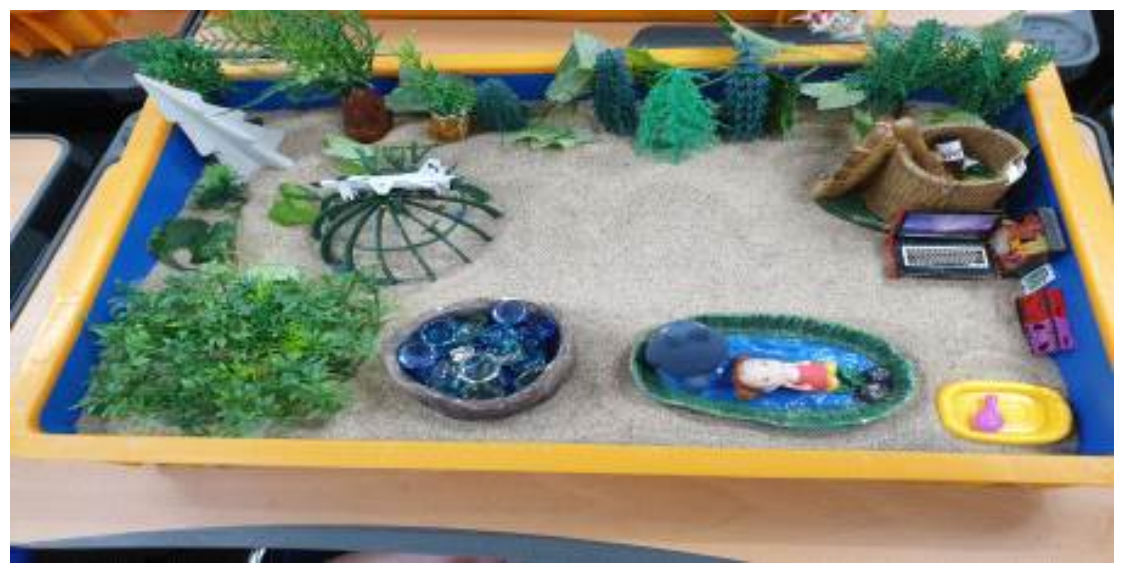

Fig 3. Sandpicture created by Child C in Session 2

\section{Story from imagination}

"I am going to make a garden (she brings a pond and a laptop figure). This child is watching a movie. The airplane crashed. The engine has fallen out. It fell into a forest. The girl is all on her own. Tororo is a doll, but it can speak. The girl watched the movie, and she is an adult. She brought all of her belongings. I think it will be quiet. I like it because it seems no one is here. Left home because family members were butting in. I feel pity for the child."

Child C, who created the sandpicture in Figure 3, stated that she stays out and plays until six in the evening because she does not want to go home. When she does come home, she spends the evening playing games on her smartphone. She said that she is extremely bored because she cannot go to school due to COVID-19, and expressed frustration against her mother, who did not allow her to go out and play. Child C's mother had recently been working long hours and arrived home late at night. Her older brother returned home at seven o'clock, so Child C was often home alone for many hours. She said that she feels scared to be home alone in the evening, and that she calls her mother on the phone to find comfort. Child C said that she sometimes feels that the smartphone is protecting her.

As a key function of the smartphone is interconnectivity, it may have helped Child C endure the times she had to spend on her own, void of communication. It seems that Child C uses her smartphone the most when she feels bored during the long hours being alone and 
Journal of Symbols \& Sandplay Therapy, Vol.12 No.1.

during the night when she is home alone. The researchers could sense desolation and loneliness in her sandpicture. A common opinion among the researchers was that despite the different types of trees and various figures she used, there was still a feeling of emptiness in her sandpicture. Child C expressed loneliness by depicting a state of being alone with no communication.

In her story, Child $\mathrm{C}$ made a connection between being alone in a forest and being home alone at night. She used the forest to express the comfort it brings to the girl left all alone, as smartphone games help her deal with the lack of communication when she is left alone at home. Child C's statement that when lonely, adults drink while children go on their smartphones enable a deeper understanding of the long hours she had to endure alone in the dark.

During the earlier sessions, Child C had her bangs cover her face, had trouble with eye contact and did not speak much. However, sandplay seemed to help her relax, and later on she was laughing a lot and responding well to the other research participants. In particular, she showed deep empathy and understanding for another research participant who expressed a desire to end life and showed signs of depression. At the same time, she felt relieved that feeling the urge to end life was shared by others. Through this experience, Child $\mathrm{C}$ started to tell her story more openly and forged deeper relationships.

\section{Striving to Protect Oneself}

\section{Scene from imagination}

The sand is piled toward the center, revealing the bottom of the sand tray toward the edges. There are people with guns, arrows, axes and gloves all aiming at one direction. A house with chapped walls and some trees are surrounding the people. There is a skull and bones behind one of the trees, and a tiger is hiding behind a tree in the back. 


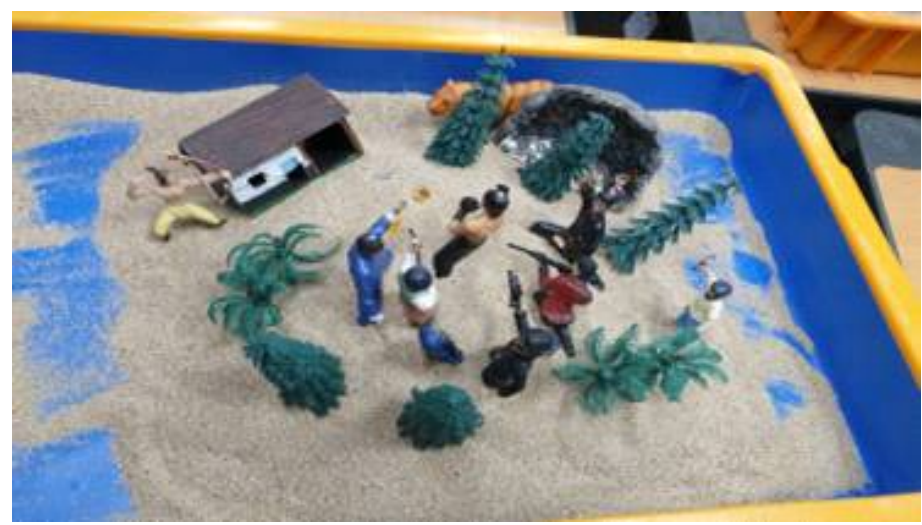

Fig 4. Sandpicture created by Child E in Session 4

\section{Story from imagination}

"I want to make an island (chooses a tray with little sand). I want to make a deserted island (takes the cup and empty sand tray from the researcher and uses the cup to measure and pour a certain amount of sand). This man is a prince (the male figure is holding a torch and knife). He came with food. He unexpectedly came to the deserted island. He prepares his own food. He finds things to eat, and there are chopsticks. He sleeps at night with the torch burning. The man feels everything happened so suddenly, and he feels strange. I think they will escape. I think they will go to the city that the man used to live. Two years later, they expand the land. Four years later (puts more sand in the sand tray), they can finally reach the land. Now, they head to the city. They still need to expand the land some more, but there is hope. Six years later, a survivor appears. They can stay together. Eight years later, they are still here but they find other people. They can escape when they find other survivors. Eighteen years later, a tiger tries to prey on them. It is a mother tiger. The people are scared. The six of them join forces to drive it away."

Child E, who created the sandpicture in Figure 4, had parents with hearing impairment. Although his parents wanted to be involved with him, their condition made it difficult for them to communicate. Child E reported that his parents often fought when he was around. Once, the fight became heated and Child E's mother sent him to the bathroom. Child E called the police to stop the fight. His father was throwing objects, and neighbors and the police came to their 
Journal of Symbols \& Sandplay Therapy, Vol.12 No.1.

house. As he was telling the story, Child E's voice became louder and faster. The child told the story spontaneously during the sessions without being asked, which indicated that he had been struggling with the incident for a long time. Child $\mathrm{E}$ would have wanted to escape from the situation to protect himself while his parents were fighting. In fact, the sandpicture he created included images that suggest a desire to be protected.

The people on the deserted island had to survive by looking for food and protecting themselves through the night with torches. They also struggled to defend themselves from the preying tiger and escape from the island. Child D also had to protect himself, and it seems that the unconscious that seeks to protect was portrayed in his sandpicture and story. One researcher felt that the house with chapped walls and the hungry tiger reveal the struggles that the child is going through as he tries to survive in a situation in which he is not protected. Another researcher felt the need for Child $\mathrm{E}$ to protect himself from the huge sense of loss when his parents did not help him in times of difficulty. Thus, the smartphone would be to Child $\mathrm{E}$ someone to talk to in place of his parents, a tool that comforts him when he is on his own and lonely, at times a tool that brightens up the dark night like a torch, and many other things.

Due to COVID-19, parent interviews were to be conducted on the phone, but because Child E's parents are deaf, the interview was conducted via video call in the presence of a sign language interpreter, who helped with communication between Child E's mother and the researcher. During the interview, Child E's mother complained about the difficulties in communicating with her child. She believed that communication was difficult because she could not speak and Child E's sign language was not good enough for them to make deep conversations. The researcher explained to her the characteristics of development in children of Child E's age and that it is hard for children in this age group to fully communicate their emotions with language. This seemed to be a relief to Child E's mother because she learned that this is not a problem that only applies to them. It seemed that for a long time, the mother had been worrying and struggling because she thought the reason Child $\mathrm{E}$ refused to have conversations with her and was obsessed with his smartphone was because of her and her husband's hearing disability. The researcher suggested that the family develop rules on 
Park, Sung Min - Jo, Yun · Jung. Hyun Kyoung / An Arts-based research on group sandplay therapy for children in local children's centers who are overly dependent on internet and smartphones experiencing the COVID-19 pandemic era

smartphone use and find something fun to do together. By doing so, they will naturally get to spend time together and the parents would be able to pay better attention to Child E's emotions, which could lead to better communication. Although Child E's family had the desire for communication, there were deep gaps in their emotional relationship due to his parents' disability, and a lack of understanding on child development stages and the proper way to communicate with children in certain age groups.

In the following group sandplay therapy session, Child E proudly stated that he kept the promise he made with his mother to shorten the time he spends on his smartphone and that he has overcome smartphone addiction. As the man who was once alone on the deserted island could escape and return to land with other people in the story, Child E seemed to have found emotional connection through communication and relationship-building.

\section{CONCLUSION}

This study conducted group sandplay therapy for children at local child centers who became heavily dependent on the internet and smartphones due to the absence of their guardians during the day amid the COVID-19 pandemic. The study observed, through the lens of Jungian psychology, how group sandplay therapy can alleviate psychological difficulties that led the children to become overly dependent on the internet and smartphones and to what extent the therapy can help resolve this problem. It also examined the symbols that appeared in the process.

The group sandplay therapy administered on children with overdependency on the internet and smartphones using the service of local child centers during the COVID-19 pandemic showed four common themes: seeking affection, suffering from anxiety, coping with loneliness and lack of communication, and striving to protect oneself. Through this study, researchers were able to know the followings:

First, through the voluntary sandplay process, which is a form of creative play and has elements of art, the emotions of the research participants were well expressed and thus the 
Journal of Symbols \& Sandplay Therapy, Vol.12 No.1.

researchers were able to understand those emotions.

Common themes emerged as various symbols in the sandplay process. Imaginary scenes and stories voluntarily created by the participants included elements of art. Huizinga said art contains creative elements, in which play elements can be found (1983/2010). The art works of the children displayed elements of creativity and play, and the symbols that contained the unconscious helped better understand the children's psyche. Winnicott explained that play is connected to not just imagination but also the personal reality (1971/1977). While the play is based on the imagination of children, it reflects their outer reality. Even in this study, children's emotions were vividly felt through their sandpictures, stories related to the sandpictures, and their facial expressions and behaviors. And the symbols and the stories told something about not only their emotions but also the circumstances they were in.

When the symbol expressed in the sandplay therapy process becomes emotionally meaningful, the researcher's interest is transmitted and this is recognized through art, literature, and dialogue (Kast, 1992). The statement was true for this study. Through the sandpictures, which can be regarded as a work of art by research participants, the audience could develop an empathy, which is what art does. Such an outcome well demonstrates McNiffs statement that because children have limitations in expressing their psychological and emotional difficulties verbally, compared to adults, the use of art as a means of psychological exploration can help understand the difficulties and resolve them (2011). Children's desires and emotions could be more clearly understood through the images and nonverbal aspect of the sandplay process, which would not have been possible through verbal means alone.

Existing studies at home and abroad discuss children's emotional state art-based qualitative research. The study of Abdulah et al. (2020) found, through children's drawing, that children feel lonely and depressed because they are unable to engage in activities that they used to prior to COVID-19. This outcome is sync with that of this study. Abdulah et al. recommended that children find positive ways to express their feelings through creative activities such as playing and drawing. This emphasizes how important it is to be able to freely express one's psychological difficulties as symbols, as is the case in sandplay which is a form of creative play.

Second, a closer look at children's individual sandpictures and their stories showed that they were greatly influenced by the surrounding environment and the relationship family members, 
Park, Sung Min - Jo, Yun · Jung. Hyun Kyoung / An Arts-based research on group sandplay therapy for children in local children's centers who are overly dependent on internet and smartphones experiencing the COVID-19 pandemic era

which implies that children not just individual support but also a social support system.

An existing study (Jo \& Koh, 2016) found that family support, friend support, school teacher support, and local child center teachers' support-which are subsets of social supporthave a negative impact on smartphone addiction prevention and intervention when taken individually. Thus, there is need for a greater social support in terms of preventing smartphone addiction and making interventions. Among them, the support of school teachers - was found to have the greatest impact, which may be due to the fact that children spend relatively more time at school than elsewhere. But at a time like this where children are having online classes at home due to COVID-19, support from teachers at local child centers and from families would be more important than support from school teachers. The participants of this study reported that they spend the longest time on the internet and smartphones on weekends, when they do not go to schools or local child centers. From this, we could surmise that regulations on smartphone usage at local child centers actually protects the children from internet and smartphone dependency. This also raises the necessity to provide an environment for play, which would replace smartphones, at home and also to offer parent education with regard to preventing smartphone addiction. In other words, it is necessary to provide children with opportunities to play actively and voluntarily and create an environment at home where imagination and creativity can be expressed naturally. In addition, adults' paying attention to children alone can serve as a support system. This means that while the use of the internet and smartphones are problems of the individual, its social aspect must also be fully considered. Therefore, it is urgent to come up with concrete and efficient intervention measures from a social viewpoint to help children with internet and smartphone overdependence problem, especially in the era of the pandemic era where online classes and social distancing are implemented.

Third, it was found that children felt lonely and isolated, and they were desperate to be with someone. When this need was not met, they became more immersed in the internet and smartphones. In particular, children using the service of local child centers experienced loneliness and disconnection of relationships even before the COVID-19 pandemic. And as their time at home was extended due to the closing of schools, their feeling of loneliness was deepened. Such 
Journal of Symbols \& Sandplay Therapy, Vol.12 No.1.

an outcome is in line with that of an existing study which reported that excessive use of smartphones deepens loneliness (Hwang \& Kim, 2017; Byun \& Kweon, 2014). When at home, these children often spend time alone or with friends via smartphones rather than interacting with their families. According to the study of Kim (2020), failing to control various psychological stresses caused by COVID-19 will aggravate the existing stress. This finding emphasizes the need to make active interventions before the severance of the relationship that children experience becomes a trauma.

Fourth, in sandplay, which is like art work, the receptive relationship formed in a group and the intersubjectivity of therapists can be considered being essential for healing to occur. Therefore, the creative and healing interventions made through sandplay can have positive effect for overreliance of the internet and smartphone. This was also shown in an existing study conducted overseas, which explored the post-traumatic growth of child disaster survivors and used art to give meaning to their traumatic experiences (Mohr, 2014). The study could see that art is a major source of exploration and healing, and that the intervention of art therapy is a natural healing experience for research participants. Such is consistent with the findings of this study. Sandplay therapy, or play, is an archetype that develops in the psyche. The manifestation of archetypal energies is experienced emotionally and brings healing and transformation (Jang \& Lee, 2020). In other words, the therapist's empathy and acceptance towards participants' sandpictures and related stories, which can be regarded as art works, would be effective in alleviating psychological difficulties caused by internal conflict. Children will suffer less from the drives of the unconscious, see an improvement in terms of their behaviors, and heal (Jang, 2018). Here, the intersubjectivity between the therapist and participants plays an important role in healing. Deep intuition of the therapist, in analytical psychology, can provide knowledge that is indeed really true and not just speculation, guesswork or fantasy (Stein, 2015). Thus, it is important for therapists to understand the symbols used by children by assuming a receptive attitude and using their therapeutic intuition.

One of the limitations of this study is that the participants are those who use the service of local child centers only at Gyeonggi province. Because the study focused on a single particular location, there is a limit to generalizing the psychological characteristics of children. 
Park, Sung Min - Jo, Yun · Jung. Hyun Kyoung / An Arts-based research on group sandplay therapy for children in local children's centers who are overly dependent on internet and smartphones experiencing the COVID-19 pandemic era

Another limitation is that only six sessions of therapy and only a single session of face-to-face meeting with the guardians took place. Extending the therapy and meeting sessions would help better understand the children and their circumstances and make more proper interventions.

The value of this study lies in the fat that it used art-based research to more vividly understand the process of group sandplay therapy of children who are overly dependent on the internet and smartphones during the ongoing pandemic. As there is a scarce number of ABR-based research on children in Korea, this study will become a helpful base for future related studies. It will also be able to provide practical information to future group programs for children with internet and smartphone dependency problem.

\section{References}

Abdulah, D. M., Abdulla, B. M. O. \& Liamputtong, P. (2020). Psychological response of children to home confinement during COVID-19: A qualitative arts-based research. The International journal of social psychiatry, 12, 1-9. doi: 10.1177/0020764020972439

Back, S-J. (2016). The Effects of Group Music Therapy focused on Creative Music Making on the Self-esteem and Self-resilience for Children in Community Child Center. Master's thesis, (Sungshin Women's University Graduate School of Education).

Barone, T. \& Eisner, E. (2012). Arts based research. Thousand Oaks, CA: Sage.

Beer, L. E. (2016). From embedded to embodied: Including music in arts-based music therapy research. Music Therapy Perspectives, 34(1), 33-40.

doi: $10.1093 / \mathrm{mtp} / \mathrm{miv} 006$

Boik, B. L. \& Goodwin, E. A. (2000). Sandplay therapy: a step-by-step manual for psychotherapists of diverse orientations. New York: W. W. Noton \& Company. (Trans. into Korean in 2012).

Byun, H-S. \& Kweon, S-Y. (2014). The Effect of Elementary School Students' Loneliness on School Life Adaptation: the Mediating Effect of Smartphone Addiction. The Journal of Child Education, 23(4), 303-317.

Caldwell, L. \& Joyce, A. (2011). Reading Winnicott. London: Routledge. (Trans. into Korean in 2015). Chung, I-J., Lee, S-J. \& Kang, H-J. (2020). Changes in Children's Everyday Life and Emotional Conditions Due to the COVID-19 Pendemic. Journal of the Korean society of child welfare. 694), 
Journal of Symbols \& Sandplay Therapy, Vol.12 No.1.

56-90.

doi: $10.24300 / j \mathrm{kscw} \cdot 2020.12 .69 .4 .59$

Eisner, E. W. (2005). Does Arts-based Research Have a Future?. Studies in Art Education, 48(1), 9-18.

Erickson, J. M. (1991). Wisdom and the Senses. New York: W. W. Noton \& Company. (Trans. into Korean in 2008).

Hong, M-H. (2005). Imagination and Gaston Bachelard. Gyeonggi: Sallimbooks.

Huizinga, J. (1983). Homo Ludens: A Study of the Play Element in Culture. Boston: The Beacon Press.

(Trans. into Korean in 2010).

Hwang, J-W. \& Kim, J-S. (2017). Children's Loneliness on Smart Phone Addiction: Focusing on Mediation Effects of Academic Stress. The Journal of Humanities and Social science, 8(4), 693-706. doi: $10.22143 / \mathrm{HSS} 21.8 .4 .35$

Im, S-H. \& Shin, H-J. (2020). The Impact of Change in Depression, Anxiety, and Loneliness on Progress of Smartphone Addiction. Korean journal of health psychology, 25(1), 273-286. doi: 10.17315/kjhp.2020.25.1.015

Jang, M-K. (2017). Analytical psychological sandplay therapy. Seoul: Hakjisa.

Jang, M-K. (2018). Play therapy. Seoul: Cangjisa.

Jang, M-K. \& Lee, Y-R. (2020). Numinose of Play and Its Healing Teleology. Symbols and sandplay therapy, 11(2), 1-43. doi: 10.12964/jsst.2006

Jeon, A-Y. (2019). The practice of group sandplay therapy. Seoul: PYMATE.

Jeong, N-R. (2012). Nietzsche and modern art. Seoul: youkrackbooks.

Jeong, N-R. (2017). human philosophy of play. Seoul: chaeksesang.

Jo, Y-Y. \& Koh, Y-S. (2016). Effect of Social Support on Smartphone Addiction among Children in Poverty from Community Children's Centers. Journal of School Social Work, 16(36), 175-199.

Jung, C. G. (1984). Archetyp und Unbewußtes. Princeton: Bollingen/Princetonn University Press. (Trans. into Korean in 2002).

Jung, C. G. (1985). Erlosungsvorstellungen in der Alchemie. Walter: Olten. (Trans. into Korean in 2004).

Jung, C. G. (1990). Mensch und Kultur. Walter: Olten. (Trans. into Korean in 2004).

Jung, C. G. (1996). Man and His Symbols. New York: J. G. Ferguson Publishing. (Trans. into Korean in 2007).

Kalff, D. M. (1980). Sandplay. Boston, MA: Sigo Press.

Kang, E-Y. (2009). A Study on Arts-Based Educational Research Methodology. The Korean Journal of Arts Education, 7(1), 45-59. 
Park, Sung Min · Jo, Yun · Jung. Hyun Kyoung / An Arts-based research on group sandplay therapy for children in local children's centers who are overly dependent on internet and smartphones experiencing the COVID-19 pandemic era

Kast, V. (1992). The dynamics of symbols: fundamentals of Jungian psychotherapy (Schwartz, S.A., Trans.). New York: Fromm International.

Kim, H-S. (2020). What children lost to Corona. Seoul: Demstory.

Kim, S-M. (2017). Analytical Psychology and Literature: The Difference of Attitude toward the Art between S. Freud and C. G. Jung. Theology and Praxis, 53, 217-254.

doi: $10.14387 /$ jkspth.2017.53.217

Kim, Y-S. (2017). The Effect of Adult Attachment on Smartphone Addiction: With Loneliness and Self-control as Mediated Variables. Master's thesis, Incheon National University Graduate School of Education.

Kweon, J-H. (2018). Save the child from the smartphone. Seoul: Motherbooks.

Leavy, P. (2008). Method meets art. New York: Guilford Press.

Leavy, P. (2015). Methoth Meets Art: Arts-Based. Research Practice. New York: Guilford Press. (Trans. into Korean in 2018).

Lee, H-J., Chae, S-M., Bang, K-S \& Choi, H-S. (2015). Relationships Among Preschoolers' Smartphone Addiction Tendency, Their Problem Behaviors, and Parenting Efficacy of Their Mothers. Child Health Nursing Research, 21(2), 107-114. doi: 10.4094/chnr.2015.21.2.107

Lee, M-J. (2017). A Study on the value of the methods of art in art-based research. Journal of art education, 50(1), 47-72.

Malchiod, C. A. \& Crenshaw, D. A. (2013). Creative Arts Play Therapy for Attachment Problems. New York: Guilford Press. (Trans. into Korean in 2019).

McNiff, S. (1988). Art-based research. London: Jessica Kingsley Publishers.

McNiff, S. (2011). Artistic expressions as primary modes of inquiry. British Journal of Guidance \& Counselling, 39(5), 385-396.

doi: $10.1080 / 03069885.2011 .621526$

Ministry of Gender Equality and Family (2020). Policy News: Diagnosis Survey of Internet and Smartphone Use Habits in 2020.

Mohr, E. (2014). Posttraumatic Growth in Youth Survivors of a Disaster: An Arts-Based Research Project. Art Therapy: Journal of the American Art Therapy Association, 31(4), 155-162. doi: 10.1080/07421656.2015.963487

Nachmanovitch, S. (1990). Free Play. New York: Peguin Group. (Trans. into Korean in 2008).

National Information Society Agency (2015). The results of a survey on smartphone overdependence in 2015 .

Park, S-J. (2020). An Art-Based Research on Suicidal Mind through the Folk Tale < The Sun and 
Journal of Symbols \& Sandplay Therapy, Vol.12 No.1.

the Moon>. Anthropology of Education, 23(3), 111-162. doi: 10.17318/jae.2020.23.3.004

Punnett, A. (2018). Jungian Child Analysis. New York: Fisher King Press.

So, H-J. (2020). Inquiry on the Application of Arts-based Research Methods for Creative Arts

Therapy. The Korean Journal of Body-Psycho Studies, Q1), 37-56.

Sohn, E-K., Choi, E-Y. \& Kong, M. (2016). The Mediating Effect of Resilience in the Impact on the Mental Health of Upper Elementary School Students' Smart Phone Addiction Risk. The Korean Journal of Rehabilitation Psychology, 23(2), 439-457.

Stein, M. (2015). Jung's Map of Seoul. Chicago, I 1: Open Court. (Trans. into Korean in 2015).

Susan, R. \& Joel, W. (2021). Jungian arts-based research and the nuclear enchantment of New Mexico. London/New York: Routlege.

Winnicott, D. W. (1991). Playing and Reality. London: Tavistock. (Trans. into Korean in 1997).

Web sites

Kim, J-Y. (2021, February, 09). COVID-19 Internet and smartphone addiction increase. Geumgan gilbo,

http://www.ggilbo.com/news/articleView.html?idxno $=827621$

Mun, D-Y. (2020, September, 08). An elementary school where social distancing is the top priority...

"I only paint by myself instead of playing tag". Yonhap News.

https://n.news.naver.com/article/001/0011866861

투고일 : 2021. 03. 31

수정인 : 2021. 05. 31

게재확정일 : 2021. 07. 01 


\title{
COVID-19 팬데믹 시대를 경험하는 인터넷, 스마트폰 과의존 지역아동센터 아동의 집단모래놀이치료에 대한 예술기반 연구
}

\author{
An Arts-based research on group sandplay therapy for children \\ in local children's centers who are overly dependent on internet and \\ smartphones experiencing the COVID-19 pandemic era
}

\author{
박 성 민 \\ 조 \\ 윤 \\ 정 현 경*** \\ Park, Sung Min \\ Jo, Yun \\ Jung, Hyun Kyoung
}

\begin{abstract}
$<$ Abstract $>$
The purpose of this study is to find a clue of psychological intervention in group sandplay therapy for children in local children's centers who are overly dependent on internet and smartphones experiencing the COVID-19 pandemic era. Art is a process of expressing imagination, and it is in line with the fact that play is a symbolic and creative activity. Therefore, it can be said that children's imaginary play scenes and imaginary stories appearing in sandplay therapy are a form of art. Sandplay enables non-verbal expression, and the unconscious contents expressed by children are useful in understanding children's emotions. In this process, the researcher understands the client through imagination which is the intersubjective method and experiences an accepting relationship where healing and change occur. However, previous studies have limitations in that they approached children's dependence on the Internet and smartphones based on language. Therefore, these researchers conducted an arts-based study from an analytical psychology perspective to understand the experiences of children in local children's centers who are overly dependent on the Internet and smartphones through the group sandplay therapy process. To this end, co-researchers attending the doctoral program in child counseling and psychotherapy have categorized and discussed four themes : 'wanting to be loved', 'suffering from anxiety', 'tolerating being alone/not communicating', 'trying to protect oneself. Finally, it was intended to alleviate the psychological difficulties of children in local children's centers who are overly dependent on internet and smartphones, and to provide an open method for resolving the Internet and smartphone dependence phenomenon.
\end{abstract}

Keywords : COVID-19 pandemic era, group sandplay therapy, overly dependent on internet and smartphones, Arts-based research

* 주저자, 허그맘 허그인 평택점 상담사 (childlove123@naver.com)

** 교신저자, 남서울대학교 아동복지학과 대학원 박사과정 (77734306@hanmail.net)

*** 공동저자, 남서울대학교 아동복지학과 대학원 박사과정 (kidskidslove@gmail.com) 
Journal of Symbols \& Sandplay Therapy, Vol.12 No.1.

\section{I. 서 론}

2020년 COVID-19 팬데믹으로 인하여 사회에 많은 변화가 일어났다. 감염병 확산을 막기 위한 사회적 거리두기가 시행되었고, 이 변화된 환경에 적응하기 위해 다양한 생활양식이 나타났다. 이러한 변화는 아동들의 일상에서도 나타났다. 학교 개학이 연기되고 거리두기로 인한 아동의 사회적 관계는 대부분 단절되었다. 그리고 온라인 수업이 장기화되며 자연스 럽게 미디어에 접촉하는 시간이 길어졌다. 인터넷, 스마트폰 사용 시간이 길어지면서 인터 넷, 스마트폰 과의존으로 이어질 수 있는 상황이 증가하였다. 인터넷, 스마트폰 과의존은 인터넷 및 스마트폰의 과다사용으로 인해 금단과 내성을 지니고 있으며, 이로 인해 일상생 활의 장애가 유발되는 상태를 초래한다(한국정보화진흥원, 2015). 여성가족부(2020)에서 인터 넷, 스마트폰 이용 습관 진단조사를 실시한 결과 초등학생의 경우 과의존 위험군이 전년도 에 비해 $16.7 \%$ 로 증가하여(금강일보, 2021) 아동의 인터넷, 스마트폰 과의존에 대한 우려가 커지고 있다.

자연스럽게 초등학교에서 실시하던 술래잡기, 축구와 같은 야외 단체 활동과 보드게임이 나 합창 등의 모든 협력 활동은 COVID-19 확산으로 인한 온라인 수업의 실시로 대부분 중 단되었다(연합뉴스, 2020). COVID-19 팬데믹 시대 이전에도 부족했던 아동들의 놀이시간은 감염병 확산으로 인해 더욱 감소했다. 현대 사회의 아동들은 마당도 정원도 없는 무미건조 한 도시 중심의 문화가 만든 생활 방식에서 주로 살고 있다. 대부분의 아동들은 학교가 끝 나면 학원으로 가는 등 학업 위주의 삶을 살고 있다. 학습 외에 남은 시간은 인터넷, 스마 트폰을 하며 대부분의 시간을 보낸다. 웹툰 시청, 인터넷 서핑, 게임, SNS를 하는 것이 이들 이 갖는 놀이 시간을 보내는 방법이다(권장희, 2018)

그중에서도 특히 취약계층과 맞벌이 부부의 자녀들은 부모의 돌봄이 부족하고 홀로 있는 시간이 길다(정익중, 이수진, 강희주, 2020). 아동들은 홀로 있는 시간이 길어지면 길어질수 록 인터넷, 스마트폰을 사용하며 보내는 시간이 많아져 과의존에 빠지게 될 가능성이 높다. 지역사회 내의 돌봄이 필요한 취약계층, 맞벌이 부부 자녀들에게 지역아동센터는 가정과 학교 사이의 또 하나의 상호보완적인 체계로서 그 기능과 역할을 수행하고 있다(백수정, 2016). COVID-19의 팬데믹으로 아동들에게 제공하는 돌봄의 공백이 더 커지면서 정부에서 는 취약계층 아동들의 지역아동센터 이용 시간을 확대하는 등의 다양한 정책을 시행하고 있다. 그럼에도 불구하고 학교에 등교하지 않는 기간에 지역아동센터 이용 아동들은 혼자 있는 시간이 늘어나면서 아동이 원하는 만큼 대인관계에서 만족하지 못하게 되며, 자신의 어떤 집단에 속하지 못할 때 발생하는 사회적 감정인 외로움을 많이 느낄 수 있다(임숙희, 신현지, 2020). 이는 사회적, 정서적 관계의 부족으로 인하여 초래되는 외로움을 많이 느낄 수록 스마트폰 중독에 빠질 가능성이 높다는 선행 연구 결과(김양수, 2017)처럼 학교에 등 
교하지 않는 기간에 아동들의 미디어 사용이 증가했다(연합뉴스, 2020). 지역아동센터 이용 아동들의 팬데믹으로 인한 혼자 있는 시간의 증가와 관계단절로 인한 트라우마는 아동들의 우울, 불안, 공격성, 충동성 같은 부정적인 정서를 증가시킬 수 있다(손은경, 최은영, 공마리 아, 2016).

본 연구는 인터넷, 스마트폰 과의존 지역아동센터 아동들의 정서적인 어려움에 대해서 인식하고 개입하기 위해 놀이를 통한 심리치료 즉 모래놀이치료를 제공하고자 하였다. 아 동들은 자신이 겪은 부정적인 경험, 두려움, 공포, 슬픔, 괴로움 등을 언어로 표현하기보다 는 놀이를 통해 표현하기 때문에 인터넷, 스마트폰 과의존에 빠질 수 밖에 없게 만드는 상 황적 어려움과 심리적 반응, 그리고 인터넷, 스마트폰 과의존으로 인한 정서의 어려움을 잘 이해하기 위해서는 놀이의 방법으로 아동들에게 적용하는 것이 적절하다(장미경, 2018).

본 연구에서 언급한 놀이의 행위는 인터넷, 스마트폰으로 하는 놀이와 다르게 상상을 모 래놀이 행위로 연결하는 창조적인 행위이다. 또한 스마트폰 게임, 영상시청과 같은 시각적 놀이는 아동들이 움직이지 않고 주로 혼자 하는 놀이다. 이는 다른 사람들과 상호작용 하 는 것을 방해하며 아동을 관계로부터 고립시킨다(이현주 외, 2015). 이런 매체의 놀이는 아 동의 상상력을 자극하지 않는다. 상상력을 앗아가는, 이미 만들어진 이미지는 아동을 수동 적으로 보기만 하는 존재로 만든다(Erickson, 1991). 이미지와 상상력의 중요성을 강조한 철 학자 Gaston Bachelard는 상상력이 단순한 재현적 이미지를 유도해 내는 능력이 아니라 새로 운 이미지를 창조해 내는 능력이라 했다(홍명희, 2005).

상상력의 산물인 아동의 놀이는 예술가의 창조활동과 비슷하다. 예술 철학자 Langer는 상 상에 대해서 추론적 이성보다 더 오래된 인간의 고유한 특성이라 칭했다. 어린 아동이 놀 이하는 모습을 보면 뭔가를 만들고자 하는 의지와 호기심의 에너지를 쏟아붓는 것을 볼 수 있다. 그리고 결과적으로 아동은 자신만의 창조물을 창조해 낸다. 이 과정은 원리 상 피카 소 같은 예술가들이 하는 작업과 다르지 않다. 결국 창조하고자 하는 충동은 같다는 것이 다(Erickson, 1991).

문학예술도 마찬가지이다. 소설 '지킬박사와 하이드'의 작가인 Robert Louis Stevenson은 어 느 날 아침 일어나 지난 밤 꿈에서 영감을 얻어 단숨에 이 소설을 완성해 내었다. 그것은 놀이처럼 미리 계획되거나 예상된 것이 아니었다. 무엇인가 마음 속 깊은 곳에서 올라온 상상과 환타지에 이끌리어 깊은 몰입 속에서 단 며칠 만에 그는 이 소설을 완성해내었다. 아동들의 놀이를 보면 그들이 방해받지만 않는다면 아동들은 깊은 몰입 속에서 놀이한다. 아동의 놀이 요소 중 중요한 것은 자발적으로 떠오른 상상, 환타지 같은 것이다. 즉 예술과 놀이의 창조하고자 하는 충동은 깊은 관련이 있다.

철학자 Nietzsche는 예술을 아동들의 놀이에 비유하여 설명하였다. 아동들의 놀이는 곧 예 술적 충동을 의미하며 모든 인간은 예술가가 된다. 인간이 놀이하는 존재이고 이런 점에서 
Journal of Symbols \& Sandplay Therapy, Vol.12 No.1.

모든 인간이 예술가이고 예술 행위는 놀이의 형태로 드러난다고 하였다. 일체의 창조행위 는 예술이라 할 수 있으며, 이것은 인간의 의식적, 무의식적 활동이 포함되어 있다(정낙림, 2012). 그러므로 아동에게 이런 자발적이고 상상을 할 수 있고 그것을 실현할 수 있는 창조 적 놀이 기회를 제공하는 것은 상상의 실현과 놀이 예술적 충동 실현의 기회를 경험하게 하는 중요한 활동이다. Winnicott 또한 놀이의 핵심요소는 창조성이며 자발적인 놀이가 중 요하다고 했다. 놀이는 본질적으로 가치 있으며, 생생하게 살아 있는 것으로 인간의 삶 일 부 예술 속에 내재 되어 있는 것이다(Caldwell \& Joyce, 2011).

Jung에 의하면, 예술에서의 창조적 행위는 무의식적인 부분에서 나오며(Jung, 1990), 무의 식에서 본성적인 부분으로 일어나는 상상은 의식에 무의식의 것을 알리기 위해 생겨나며, 이것은 이미지로 표현된다(Jung, 1985; 장미경, 2018)고 하였다. 상상의 실현과 놀이 예술적 충동은 인간성의 전체성 회복에 결정적인 역할을 하며, 모든 인간의 행위를 예술적인 활동 으로 이해함으로써 예술행위로서 놀이를 창조성의 시작점이자 예술이 되게 하는 중요한 요 소를 가지고 있다(Nachmanovitch, 1990). 즉 놀이에는 예술적 충동이 포함되어 있으며 본성적 인 부분에 속하는 창조행위 또한 포함되어 있다.

놀이가 창조행위와 연결 되어 있음을 내포하는 언어개념이 있다. 고대 인도어인 산스크 리트어로 '릴라’는 논다는 뜻으로 창조와 파괴, 그리고 재창조가 이어지는 놀이, 성스러운 놀이를 의미한다(Nachmanovitch, 1990, p.17). 이처럼 원형적이고 본성적인 놀이는 깊은 무의 식의 본질을 만나게 함으로써 자아의식성의 갈등이 치유 받게 하고 더욱 창조적인 방향으 로 삶을 살아가게 한다(장미경, 2017). 그러나 문명화된 현대 사회에서 아동들은 본능과 같 은 무의식과의 접촉을 할 기회를 잃어버린 채 살아가고 있다(Kast, 1992). 인간은 여느 동물 과는 달리 생존을 위한 기본 옥구를 충족하는 것만으로 만족할 수 없는 존재이기 때문에 (정낙림, 2017) 놀이기회의 경험은 충분히 주어져야 한다. 이러한 점에서 놀이는 아동에게 있어서 본성과 밀접한 관계가 있으며, 원형적 충동이라고 할 수 있다.

Jung의 원형은 인류가 생긴 이래로 인간이 가지고 있는 타고난 것이며 유전에 의해 전달 되는 정신의 구조이다(Jung, 1984). 인간의 정신 안에 원형적 에너지가 배열되면 자아의지에 의한 목적성이 약화되고 시간이나 숫자와 같은 자아의식성이 감소하며 계획보다는 즉흥성 을 갖게 되고 정서적인 강력한 끌림과 자발성을 경험하며 그 경험을 지속하고자 하는 열망 을 갖게 된다. 이 때 원형에너지의 배열은 상상 또는 환타지의 형태로 떠오른다. 예술을 놀 이와 연결시켜 본다면 많은 예술가들이 내면에서 떠오르는 영감을 기다리면서 인내의 시간 을 보내는 이유와 동일한 원리라고 할 수 있다. Winnicott은 창조적 충동은 예술가와 예술 작품을 만들어 내기 위해서만 필요한 것이 아니라 누구라도 필요하다고 하였다(Winnicott, 1991). 이처럼 놀이에서 나타나는 집중의 상태와 유사한 거의 빠져 있는 상태에 들어가는 것, 쉽게 침범을 용납하지 않는 그 상태가 필요하며 마음껏 자신의 창조적 충동을 표현할 
수 있는 기회를 아동들은 필요로 한다.

Jung은 무의식의 강력한 힘은 예술, 또는 인간이 스스로 표현하는 문화적 영역에서 즉 창조적인 모든 작업에서 이루어진다고 한다. 그리고 무의식은 미지의 성질을 지닌 것을 직 관적으로 파악하고 원형적으로 처리한다. 원형은 자체의 에너지를 가지게 된다. 또한 이 원 형은 자율성을 지니고 있기 때문에(Jung, 1996), 자연스럽게 본성과 무의식적인 측면과 접촉 하게 된다. 원형은 충동의 상으로서, 심리학적으로 인간 본성이 지향하는 정신적 목표라 한 다(Jung, 1984, p.78). 따라서 놀이를 통해, 놀이로 예술적 충동을 표현하고 창조행위를 하는 것은 아동에게 무의식적으로 본성이 표현되는 창조 과정에서 치유와 변화가 종종 일어나기 도 한다. 이는 놀이 뿐 아니라 예술에서도 마찬가지이다. 예술 또는 예술가의 목표가 처음 부터 치유에 있지는 않지만 창조 과정에서 치유와 변화는 일어난다. 상상, 환타지가 갖고 있는 원형적, 무의식적 힘에 의해 이끌리어 창조행위에 이르게 되는 것이다.

Jung은 '적극적 상상'이라는 방법을 자신이 치료하는 이들에게 적용하였다. '적극적 상상' 은 상상을 통하여 명상하게 하고 이들에게 무의식과의 접촉을 시도하려고 하면서 마음의 현상과 의식적인 관련을 가지면서 마음을 치유하려고 하였다(Jung, 1996). 다시 말해 '적극 적 상상’을 통해 무의식의 메시지를 발견할 수 있게 된다. 원형은 이미지로 나타나며 역동 적이며 신성력이 있다. Jung은 꿈, 혹은 상상의 사고 형태는 무의식적 동기에 이끌려 자연 스럽게 작업할 수 있다고 한다. 이러한 무의식적인 작업은 우리 정신의 본능적인 부분이 포함되며 상징으로 나타난다(Jung, 1984).

본 연구의 연구자들은 상상을 사용하고 상징을 이용하는 모래놀이를 아동들에게 제공한 다면 치유하는 데 도움이 될 것이라 생각했다. 다시 말해서 본 연구의 연구자들은 상담 현 장에서 놀이치료사로서 아동의 본성인 놀이 기회를 얻지 못하고 특히 COVID-19로 인한 놀 이 결핍으로 스마트폰 과의존 문제가 심각해지는 것을 인식해왔다. 아동들의 무의식을 잘 나타낼 수 있고 본능과 상상력을 통한 창조적 놀이는 예술이 가지고 있는 치유의 속성처럼 자발적인 놀이를 한다면 치유를 할 수 있을 것이다(장미경, 2018). 이러한 모든 설명은 모래 놀이치료의 기본 치유가정이 인간 정신에 타고난 치유력이 있다고 보는 것이며 타고난 정 신의 치유력은 판타지, 모래놀이, 그 밖에 기타 표현예술 등에서 창조적 상상을 통해 이미 지로 표현되어 상징에 투사되기 때문이다(장미경, 2017).

모래놀이치료는 무의식 즉 내면의 상상이나 환타지적 이미지를 모래상자, 모래, 피겨 등 에 투사하고 그 의미를 이해하고자 하는 심리치료 접근이다. 무의식에서 비롯되는 상상력 은 삶을 끓임없이 새롭게 하는 능동적 변화의 원동력이고, 창조의 원천이 된다. Jung이 상 상력에 주목하게 된 것도 상상력이 가진 창조와 치유 변화적 특성 때문이다. 상상력은 단 순히 떠오른 이미지를 그대로 재현하는 것이 아니라 재현한 이미지를 통해 이미지 너머의 심층, 즉 의식이 알지 못하던 것을 이해할 수 있도록 방법으로 표현된다(김성민, 2017, Jung, 
Journal of Symbols \& Sandplay Therapy, Vol.12 No.1.

1990). 따라서 모래놀이에서는 이성적인 사고 대신에 무의식이 이야기할 수 있게 한다. 무 의식의 소통 방식은 언어뿐 아니라 비언어적 방식을 포함한다. 비언어적인 표현을 할 수 있는 모래놀이를 통해 깊은 내적 경험이 내담자와 상징적으로 표현되고 전달될 수 있다 (Boik \& Goodwin, 2000). 모래놀이치료 과정에서는 대화가 포함되지만 행동을 통한 자기표현 이 의사소통의 주요 원천이 되어 비언어적 접근방식으로 정의된다. 아동은 항상 감정과 경 험을 정확하게 담아서 말을 하는 것이 아니기 때문에(Malchiod \& Crenshaw, 2013) 아동에게 있어 의사소통의 비언어적 수단은 치료에서도 중요한 부분을 차지한다.

COVID-19로 인해 관계 단절을 경험하고, 놀이의 기회가 줄어든 아동들에게 집단모래놀 이치료의 개입을 적용하여 아동들이 자신의 감정을 놀이로 표현하고 상호작용 한다면 의미 가 있을 것이다. 그리고 인터넷, 스마트폰 사용 시간이 늘어난 아동을 직접 만나 감정을 교 류하고 수용해주는 치료자의 태도는 이들의 단절된 관계 회복 및 심리적 어려움을 치유하 는 데 효과적일 것이다. 따라서 연구자는 취약계층에 속한 지역아동센터를 이용하는 인터 넷, 스마트폰 과의존 아동에게 집단모래놀이치료를 실시하기로 하였다. 아동들은 인터넷, 스마트폰 사용을 조절하고 싶어도 스스로 조절하기 어렵기 때문에 집단에서 자연스럽게 그 들의 이야기를 듣고 함께 놀이 할 수 있는 기회를 제공하는 것이 필요하다.

집단모래놀이치료의 참여구성원들은 창조적 에너지에 의해 자연스럽게 공감 분위기가 이 루어지면서 힘든 부분이나 감정이 혼자만의 것이 아닌 유사한 힘ㄷㄻㄻㅇㅢ 경험을 비언어적 의 사소통의 수단을 통해 위안을 얻게 하는 장점이 있다(전애영, 2019).

모래놀이치료에서 주요한 요소 중 하나는 치료자의 수용적인 태도이며 이때 치료자는 놀 이 관계에서 치료자 자신의 상상이라는 상호주관적 방식을 통해 내담자를 이해하게 된다. 분석심리학에서는 이것을 직관이라고 부르기도 한다. 모래놀이치료 과정에서 내담자는 무 의식적으로 피겨를 선택하고 자발적인 상상에 의해 모래 장면을 만들게 되는데, 이는 나중 에 의식적으로 모래장면과 자신에 대해서 이해하게 되는 경험을 하게 된다(장미경, 2017). 이러한 상호주관성과 관련해서 분석심리학적 모래놀이치료자인 Ravitz는 상상력 있는 놀이, 예술, 그리고 모래놀이를 통해 치료자의 신체감각에 귀를 기울이고 내담자와 상담 중 드러 나는 비언어적 행동, 태도, 감정, 이미지에 주의를 기울여야 한다고 했다. 이러한 태도는 치 료자가 내담자와 직관적으로 연결되고 내담자의 정신을 깊이 있게 이해할 수 있도록 해준 다(Punnett, 2018).

모래놀이치료에서는 비언어적인 측면과 상상으로 표현되는 내담자의 정신을 깊이 이해하 고 연구하기에는 양적연구의 데이터 정량화와 통계적 방법의 인과관계 적용으로는 전체 이 야기를 다룰 수 없는 한계가 있다(Barone \& Eisner, 2012). 따라서 모래놀이치료 과정에서의 언어, 비언어적인 표현에 대하여 연구하기 위해 연구자의 직관력과 상징적 은유적 사고능 력(Leavy, 2015)을 강조하는 예술기반 연구 방법을 본 연구에 적용하였다. 예술기반 연구는 
자료 생성, 분석 해석 및 발표를 포함한 사회 연구의 모든 단계에서 연구자가 사용하는 일 련의 방법론적 도구로서 이론과 실천이 서로 연관되어 있으며 전체론적이고 참여적인 방식 으로 연구 문제를 해결하기 위해 창의적 예술 원리를 채택한다(Leavy, 2015). 예술치료 분야 에서 예술기반 연구를 사용하는 것은 예술의 고유한 기능과 역할 및 경험을 전달하는 데 유용하며(소혜진, 2020), 예술이 의미를 창조하고 전달할 수 있다고 가정한다(Barone \& Eisner, 2012). 또한 예술기반 연구는 다양한 설명, 발견 및 문제해결방법을 통해 통찰력을 제공한다. 예술기반 연구방법 적용의 목표는 개인이 타인의 삶과 연구 상황에 공감적으로 참여할 수 있도록 표현 형식을 만드는 것이다(Susan \& Joel, 2021).

본 연구는 기존의 예술기반 연구에 더하여 이 방법을 통해 알아가고자 하는 지식에 대해 무의식, 심혼(psyche)의 메시지를 의식화하는 것이라는 Jung학파 심리학의 관점을 기반으로 하고자 한다. 그럼에도 불구하고 궁극적으로 알게 되는 것은 동일한 것이라고 추측해 볼 수 있다. COVID-19의 발생으로 부모를 포함한 보호자의 낮 동안의 부재, 사회적 관계의 단 절, 그로 인한 인터넷, 스마트폰 과의존 지역아동센터 아동들을 대상으로 모래놀이치료를 실시하여 인터넷, 스마트폰 과의존 아동들에게 놀이기회를 제공하고 아동들의 심리적 어려 움을 완화하며 인터넷, 스마트폰 과의존 현상의 감소 가능성과 그 과정에서 표현되는 상징 에 대해 분석심리학적 관점에서 모래놀이치료 과정을 연구하고자 한다.

\section{ㅍ. 연구방법}

\section{1. 예술기반 연구}

사회과학 연구가 등장한 이후 연구자들의 연구를 바라보는 관점과 방법론은 지속적으로 변화하고 있다. 초기사회과학의 양적연구 패러다임인 실증주의에서는 연구 과정과 독립적 인 실제가 존재한다고 주장하며 이러한 실제는 중립적 입장의 연구자가 사용하는 객관적인 도구를 통해 인과관계를 발견하고 측정할 수 있다고 하였다(Leavy, 2015). 그러나 이러한 실 증주의적이고 이원론적인 양적연구의 한계로 질적연구라는 대안적 패러다임이 등장했는데, 질적연구 패러다임은 조작되지 않은 자연스러운 상황 내에서 개인이 부여한 의미, 해석에 기반하여 현상을 이해하고자 한다(강은영, 2009). 그러나 질적연구에서도 기록된 자료들을 코드화하고 범주로서 연결하여 논리성, 체계성, 연관성 등의 기준에 따라 연구의 가치를 두 는 양적인 측면으로 평가되고 있다(이미정, 2017). 이에 대한 질적연구의 보완적 패러다임으 로 예술을 기반으로 한 연구라는 새로운 사고의 전환이 일어났다(Leavy, 2008).

예술기반 연구(Arts-based research)는 그림, 조각, 영화, 비디오에서 발견되는 이미지, 혹은 
Journal of Symbols \& Sandplay Therapy, Vol.12 No.1.

음악의 소리 패턴, 역동적 춤, 또는 언어 형태의 문학이나 시 등 예술적으로 표현된 하나 이상의 형태를 주요 의사소통 수단으로 사용하는 연구방법이다(Eisner, 2005). 예술기반 연구 에서 연구 문제의 제시 방식에 예술을 도입함으로써 연구범위와 목적이 방대한 열린 텍스 트로 제시될 가능성은 독자의 사고를 열고 문제에 대한 접근의 동기를 제공한다(이미정, 2017). 기존의 언어에 주로 의존하던 질적연구의 표현 양식의 경계가 사라지고 경험을 마주 하고 대표하는 방식을 다양화 한다(Barone \& Eisner, 2012).

예술은 즉각적이며 공감각적으로 전달하기 때문에 정서적 측면의 지식을 전달하는데 매 우 효과적이다(Leavy, 2015). 예술적 경험은 사람들을 다르게 보고 생각하게 하고 더 깊이 느낄 수 있게 함으로써 상호적이고 심층적인 공감 및 직관적인 이해할 수 있게 한다(Beer, 2016). 공감과 이해를 통해 알고자 하는 것을 구체화 시키고 확장하여(Leavy, 2015) 연구가 보여주는 새로운 관점을 독자들에게 충분히 전달하고 참여시킬 수 있다.

예술기반 연구에서는 연구자, 연구참여자, 독자 간의 경계를 해체하고, 연구를 진행하고 접하는 모든 이들의 반응과 인식 및 공감을 확장하는 데 연구의 가치를 두기 때문에(박소 정, 2020) 예술기반 연구의 '예술'은 전문적 예술 또는 예술전문인의 예술만을 의미하지 않 는다(Susan \& Joel, 2021). 인간의 예술적 감성, 인간의 본성을 표현하는 것이면 그것이 어떤 재료, 어떤 표현기법이든 넓은 의미의 창조적 예술에 포함된다. 따라서 포괄적이면서 창조 적인 예술이라는 형식을 통해 세상을 생생하게 담을 수 있고 불확실하거나 확실성을 확보 하기가 더 어려운 경험에 접근할 수 있게 한다. 그러므로 본 연구에서 아동이 예술에서처 럼 창조하고 상상력을 가지고 놀이할 때 관찰자로 하여금 더 알아차릴 수 있게 도와주는 형태로 변화시키기 때문에 아동이 제공하는 의식과 통찰력은 관찰자의 이해를 가능하게 한 다. 그런 면에서 본 연구에서는 예술기반 연구의 방법을 적용하는 것이 적절하다고 할 수 있다.

이와 같은 의미에서의 예술기반 연구는 이미 Jung학파 심리학에 존재하는 것들이다. Jung 학파 심리학에서 무의식의 존재는 알려지지 않은 불완전함을 의미하며 인격의 전체성을 향 해 내재된 욕동인 심혼(psyche)을 통해 알려진 것과 알려지지 않은 것을 연결하고자 한다 (Susan \& Joel, 2021). 즉 무의식을 의식화하여 의식의 범위를 넓히고자 한다. Jung학파의 심 혼(psyche)은 의식의 이해가 가능한 존재의 형태로 항상 이미지를 산출하고 이 이미지는 상 징에 투사되어 무의식이 의도하고 영향을 미치는 바를 간접적으로 이해할 수 있게 한다(장 미경, 2017). 이런 상징이해 과정에서 상상 이미지와 충동의 요소를 경험하게 된다(Stein, 2015) 따라서 이미지는 궁극적으로 상상, 환타지에서 기인하는 것이기 때문에 상상, 환타지 에서 예술이 시작된다는 것을 감안할 때 놀이도 넓은 의미의 창조적 예술이라고 할 수 있 다(장미경, 이여름, 2020). Jung학파 심리학에서는 무의식적 지식에 무지할 때 의식 및 의식 의 중심인 자아는 심리적 문제로 고통 받게 된다. 따라서 모래놀이치료와 같은 심리치료는 
모래놀이라는 창조적 예술 방법을 사용하여 각자의 무의식이 말하는 목소리에 귀 기울이고 자 하며 그 결과로 인격의 확장과 치유를 도모한다.

이러한 가정 및 이론적 패러다임에 근거하여 본 연구에서는 융학파 예술기반 연구 방법 을 적용하였다. 이는 기존의 연구 방법에서 전달할 수 없는 고유한 예술적 경험을 탐구하 여 알려지지 않은 것의 본질의 진실을 이해하고 인식을 확장하는데 가치가 있으며(Barone \& Eisner, 2012), 아동의 심리적 치유가 일어날 것이라고 보았다.

\section{2. 연구참여자}

본 연구는 경기도에 위치한 지역아동센터 이용자 10 13세 아동들에게 한국정보화진흥원 청소년인터넷중독관찰자척도(K-척도)를 활용하여 연구참여자를 선정하였다. 청소년인터넷중 독 관찰자척도(K-척도)는 15 문항으로 구성된 4점 Likert 척도이며, 1 요인 일상생활장애(5문 항), 2 요인 가상세계지향성(2문항), 3요인 금단(4문항), 4 요인 내성(4문항)의 4 개 하위요인으로 구분되어있다. 본 척도는 $15 \sim 60$ 점으로 점수가 높을수록 인터넷 중독이 심각함을 의미한다. 고위험군은 총점 30 점 이상이거나 일상생활장애 14 점, 금단 12 점, 내성 11 점 이상인 경우이 고, 잠재적 위험군은 총점 28점이상 29점이하이거나 일상생활장애 13점, 금단 11 점, 내성 10 점 이상인 경우이며 이외의 경우는 일반 사용자군으로 분류한다. 청소년인터넷중독 관찰 자척도(K-척도) 결과 인터넷중독의 위험이 높은 고위험군 아동들을 연구참여자로 선별하였 다. 연구참여자는 5 6학년 6명(남아 3명, 여아 3명)과 3 4학년 아동 5명(남아 2명, 여아 3 명)이다. 연구참여자의 일반적인 인적사항은 표 1 과 같다.

\section{3. 연구절차}

본 연구는 집단모래놀이치료를 시작하기 전 연구참여 보호자, 연구참여자, 지역아동센터 장 및 담당 사회복지사에게 연구의 목적과 프로그램 진행 과정에 대해 안내한 후 서면동의 를 받았다. 집단모래놀이치료 프로그램은 5 6학년 집단과 3 4학년 집단을 총 2그룹으로 구성하여 1 회기 90 분씩, 각 6 회기를 두 그룹 순차적으로 진행하였다. 집단모래놀이치료 회 기는 총 6회기 이루어졌고 기간은 2020년 7월 15일부터 2020년 11월 18일까지였다. 이 시 기 동안 연구참여자들의 학교 등교 상황은 COVID-19 감염자가 증가된 정도에 따라 일주일 에 1 2번 등교하거나 등교하지 않고 가정에서 전면 온라인 수업으로만 진행되는 상황이었 다. COVID-19의 감염이 심각해지는 시기에는 사회적 거리두기 격상으로 2 주간 본 연구인 집단모래놀이치료를 중단하였다가 재개하여 진행하였다.

모래놀이치료는 Dora Kalff(Kalff, 1980)가 제시한 '자유롭고 보호받는 공간'을 제공하기 위 
Journal of Symbols \& Sandplay Therapy, Vol.12 No.1.

표 1. 연구참여자 일반적인 인적사항

\begin{tabular}{|c|c|c|c|c|c|}
\hline 연구참여자 & 성별 & 연령 & $\begin{array}{l}\text { 인터넷중독수준 } \\
\text { 선별검사 } \\
\text { (K-척도) }\end{array}$ & $\begin{array}{l}\text { 가족관계 및 } \\
\text { 가족특성 }\end{array}$ & 주호소 \\
\hline 아동A & 여 & 10 & 32(고위험군) & 부모와 함께 지냄 & $\begin{array}{l}\text { 스마트폰 사용시간 조절이 } \\
\text { 어려움 }\end{array}$ \\
\hline 아동B & 여 & 10 & 32(고위험군) & $\begin{array}{l}\text { 부모의 이혼으로 현재 모, 언니 } \\
\text { 와 함께 지냄 }\end{array}$ & $\begin{array}{l}\text { 감정조절이 어렵고 짜증이 } \\
\text { 많음 }\end{array}$ \\
\hline 아동C & 여 & 10 & 31(고위험군) & $\begin{array}{l}\text { 부모, 아동의 오빠와 함께 지냄. } \\
\text { 부모는 맞벌이 부부이며 귀가가 } \\
\text { 늦음 }\end{array}$ & $\begin{array}{l}\text { 부모의 늦은 귀가로 아동 } \\
\text { 의 오빠와 함께 있거나 혼 } \\
\text { 자 있는 시간이 많음 }\end{array}$ \\
\hline 아동D & 남 & 10 & 32(고위험군) & $\begin{array}{l}\text { 현재는 조모, 외삼촌, 아동의 형 } \\
\text { 과 함께 지냄. } \\
\text { 모의 심한 우울증으로 아동을 } \\
\text { 방임함 }\end{array}$ & 충동적이며 산만함 \\
\hline 아동E & 남 & 10 & 45(고위험군) & $\begin{array}{l}\text { 부모, 동생과 함께 지냄. 부모에 } \\
\text { 게 청각장애가 있음 }\end{array}$ & $\begin{array}{l}\text { 아동은 산만하고 타인의 } \\
\text { 관심 끌기 위해 많은 이야 } \\
\text { 기를 함 }\end{array}$ \\
\hline 아동F & 여 & 12 & 52(고위험군) & $\begin{array}{l}\text { 부모의 이혼으로 } 1 \text { 년간 부모와 } \\
\text { 분리되어 보육원에서 지냄. 현 } \\
\text { 재는 모, 여동생과 함께 지냄 }\end{array}$ & $\begin{array}{l}\text { 학교나 지역아동센터 선생 } \\
\text { 님과 갈등이 많으며 규칙 } \\
\text { 을 지키기 힘들어 함 }\end{array}$ \\
\hline 아동G & 여 & 13 & 30(고위험군) & $\begin{array}{l}\text { 부는 부재하였고, 모는 아파서 } \\
\text { 병원에 자주 입원하여 아동의 } \\
\text { 언니와 대부분 함께 있음. } \\
\text { 언니와 교류가 거의 없음 }\end{array}$ & $\begin{array}{l}\text { 혼자 있는 시간이 많고 우 } \\
\text { 울감을 표현 할 때가 많음 }\end{array}$ \\
\hline 아동H & 여 & 13 & 34(고위험군) & $\begin{array}{l}\text { 부모의 늦은 귀가로 집에 혼자 } \\
\text { 있는 시간이 많음 }\end{array}$ & $\begin{array}{l}\text { 심리적으로 위축된 모습을 } \\
\text { 보임 }\end{array}$ \\
\hline 아동I & 남 & 13 & 35(고위험군) & $\begin{array}{l}\text { 부모, 아동의 동생과 함께 지냄. } \\
\text { 부부 다툼이 많음 } \\
\text { 부는 알콜중독이며 폭력적인 모 } \\
\text { 습을 보일 때가 있고 모는 우울 } \\
\text { 증이 있음 }\end{array}$ & $\begin{array}{l}\text { 충동적이며 산만함. } \\
\text { 또래와의 관계가 어려움 }\end{array}$ \\
\hline 아동J & 남 & 13 & 34(고위험군) & $\begin{array}{l}\text { 부는 부재하였고 모는 아동을 } \\
\text { 방임하였음. 현재 조모, 외삼촌, } \\
\text { 아동의 동생과 함께 지냄 }\end{array}$ & $\begin{array}{l}\text { 감정조절이 어렵고 집단규 } \\
\text { 칙을 지키지 않아서 선생 } \\
\text { 님들과 갈등이 많음 }\end{array}$ \\
\hline 아동K & 남 & 13 & 39(고위험군) & $\begin{array}{l}\text { 부모와 함께 지냄. 부모는 맞벌 } \\
\text { 이 부부이며 귀가가 늦음 }\end{array}$ & $\begin{array}{l}\text { 집에 혼자 있는 시간이 } \\
\text { 많음. 친구들과 어울리지 } \\
\text { 못함 }\end{array}$ \\
\hline
\end{tabular}


해 비지시적 접근으로 진행하였다. 연구참여자들은 각각 개별 모래놀이장면을 만들었다. 집 단모래놀이치료를 진행하면서 보호자들과 면담이 필요하다고 판단하여 지역아동센터장, 지 역아동센터 담당 사회복지사, 5 6학년 집단 아동 보호자를 대상으로 총 90 분간 대면상담 을 하였다. COVID-19가 심각해지는 시기에 진행한 3 4학년 집단 아동 보호자들은 대면으 로 진행할 수 없어 전화상담으로 개별 교육 및 면담을 진행하였다.

연구자들은 집단모래놀이치료 매 회기와 전 과정이 종료된 이후 연구자들이 아동에 관한 자료, 아동의 모래장면 사진, 아동이 언급한 상상이야기, 아동의 행동 관찰, 연구자가 아동 들과 있을 때 연구자에게 떠오른 생각, 감정, 느낌 등을 다른 연구자들과 공유한 후 자유롭 게 떠오른 상상과 느낌을 나누고 기록했다. 이를 통해 연구자들은 연구참여자의 모래놀이 치료 과정을 상호주관성의 관점으로 바라보며 이해하고자 하였다.

\section{4. 자료 수집 및 분석}

본 연구의 방법은 예술기반 연구의 다양한 예술의 형태 중 창조적 예술인 모래놀이로 진 행되었다. 연구참여자들이 상상하여 표현한 모래놀이장면, 장면에 대한 상상이야기, 연구자 들의 떠오른 상상, 상호주관적 느낌을 연구의 주된 자료로 활용하였다. 모래놀이 장면 의미 를 통합적으로 이해할 수 있도록 아동의 배경정보, 비언어적 행동을 포함한 관찰기록지, 연 구참여자의 언어 전사본, 연구참여 보호자 및 담당 사회복지사와의 면담내용 기록지를 수 집하였다.

집단모래놀이치료 과정에서 수집된 총 56개의 개별모래놀이장면, 장면에 대한 상상이야 기, 아동에 대한 종합적인 정보를 분석심리학적 관점으로 분석하였다. 이후 분석한 결과 자 료에서 의미있게 다가오는 내용을 기록하였고 공통적으로 나타난 주제를 범주화하여 구체 화하였다.

\section{5. 연구의 진실성}

예술기반 연구에서 진실성 및 타당도를 확보하기 위해 맥니프(McNiff, 1988, 박소정, 2020 재인용)는 연구를 함께 탐구할 팀을 구성할 것을 제안했는데 이와 같은 팀은 공동연구자가 되기도 한다. 예술기반 연구를 수행하는 데 있어 2 인 이상이 참여하는 팀을 구성할 것을 다음과 같은 근거로 제안하였다. 첫째, 집단이 주는 다양한 역동과 창조성으로 인해 연구 주제에 대한 앎이 깊어질 수 있다. 둘째, 함께 연구를 수행하는 이들의 의견이 예술기반 연 구의 타당도에 대한 가장 중요한 지표로 활용될 수 있다. 이는 삼각검증의 기법을 활용한 것이라 할 수 있다. 공동연구자의 합의된 검증을 통해 연구를 설명하고 해석하며 평가할 
Journal of Symbols \& Sandplay Therapy, Vol.12 No.1.

수 있는데, 각각의 공동연구자가 말하는 것은 다른 사람의 타당성이 연구에 뒷받침된다고 할 수 있다(Eisner, 2005).

본 연구는 박사과정에서 아동상담 및 심리치료 전공을 하고 있는 3 인이 공동연구를 수행 하였다. 그 중에서도 집단모래놀이치료를 진행한 연구자는 석사부터 박사과정까지 아동상 담 심리치료를 전공하고 있다. 한국임상모래놀이치료 학회에서 모래놀이치료 분석과정, 모 래놀이치료 슈퍼비전, 학술대회를 다년간 참여한 경험이 있다. 또한 한국임상모래놀이치료 학회에서 모래놀이치료 1 급 자격증을 취득하였으며 다수의 개별 놀이치료와 모래놀이치료, 집단상담 등 10 년 이상의 아동상담 임상경험이 있다. 본 연구의 연구자들은 아동의 놀이에 대한 중요성을 인식하고 있고, 아동들과 모래놀이 과정에서 의미를 찾고 분석하는 과정을 위해 꾸준한 훈련과 오랜 시간 고민해왔다.

연구자들은 본 연구의 상호주관성을 위해 모래놀이치료 회기 진행 시와 회기를 마친 이 후에도 주 1 회 토론을 진행하며 심층적으로 논의하고 연구하였다. 또한 연구참여자의 면담, 행동관찰, 연구자의 생각과 느낌, 모래놀이장면과 상상이야기에 언급된 내용을 살펴보는 등 연구결과에 대한 진실성과 타당도를 위하여 공동연구자와 지속적인 대화를 나누며 삼각검 증법을 활용할 수 있도록 하였다. 이후 분석심리학적 모래놀이치료 전공교수 1 인에게 검수 를 받고 수정-보완하였다. 연구자들의 해석은 모래놀이치료 전문가에게 조언을 구하여 더 욱 심도 있는 해석과 분석을 할 수 있도록 했다.

\section{III. 연구결과}

COVID-19 팬데믹 시대를 경험하는 인터넷, 스마트폰 과의존 아동은 상상의 모래놀이장 면을 표현하였고, 장면에 대한 상상이야기를 하였다. 모래놀이장면에서 나타난 이미지들은 예술의 원재료가 되며, 예술로 나타난 이미지를 통해 개인 그리고 집단 안에서 소통하고자 한다(Susan \& Joel, 2021).

상상의 모래놀이장면과 장면에 대한 상상이야기에 나타난 공통주제는 4 가지로 범주화되 었고, 각 주제는 표 2와 같다.

\section{1. 사랑받고 싶음}

\section{1) 상상의 장면}

모래장면 정중앙에는 변기 위에서 아기가 술을 먹고 있다. 아기 주변의 동물들 앞에는 다양한 음식이 놓여져 있으며, 아기와 동물들은 서로 다른 방향을 향해 술을 마시고 있다. 
박성민 · 조 윤·정현경 / COVID-19 팬데믹 시대를 경험하는 인터넷, 스마트폰 가으존 지역아동센터 아동의 집단모래놀이치료에 대한 예술기반 연구

표 2. 모래놀이장면과 상상이야기에 나타난 공통적 주제와 내용

\begin{tabular}{cl}
\hline 주제 & \multicolumn{1}{c}{ 내용 } \\
\hline \multirow{2}{*}{ 사랑받고 싶음 } & $\begin{array}{l}\text { 많은 음식이 필요함. 엄마와 아기가 함께함, SNS에서 인기가 많아지길 원 } \\
\text { 함, 동물들이 사람의 마음을 알아주고 사랑해줌, 친구 사귀기를 원함, 누군 } \\
\text { 가와 소통 하고 싶어함 }\end{array}$ \\
\hline \multirow{2}{*}{ 불안에 시달림 } & $\begin{array}{l}\text { 언제 터질지 모르는 화산, 자동차, 비행기 등의 갑작스런 사고, 공격하는 } \\
\text { 괴물, 길을 잃음, 세상이 파괴됨 }\end{array}$ \\
\hline \multirow{2}{*}{ 혼자임/소통없음을 견딤 } & $\begin{array}{l}\text { 사람들이 떠난 무인도, 사막, 아무도 없는 장소에서 혼자 지냄, 혼자하는 } \\
\text { 스마트폰, 사람과 소통 없이 노트북만 하는 사람, 술을 마시는 사람 }\end{array}$ \\
\hline \multirow{2}{*}{ 스스로 자신을 } & $\begin{array}{l}\text { 죽음의 위기에 처한 동물을 보호하려고함, 가족을 죽인 사람들에게 복수함, } \\
\text { 버려진 동물을 보호함, 음식을 두고 싸움, 가출하여 안정된 공간으로 감, } \\
\end{array}$ 채임입자로부터 집을 지킴 \\
\hline
\end{tabular}

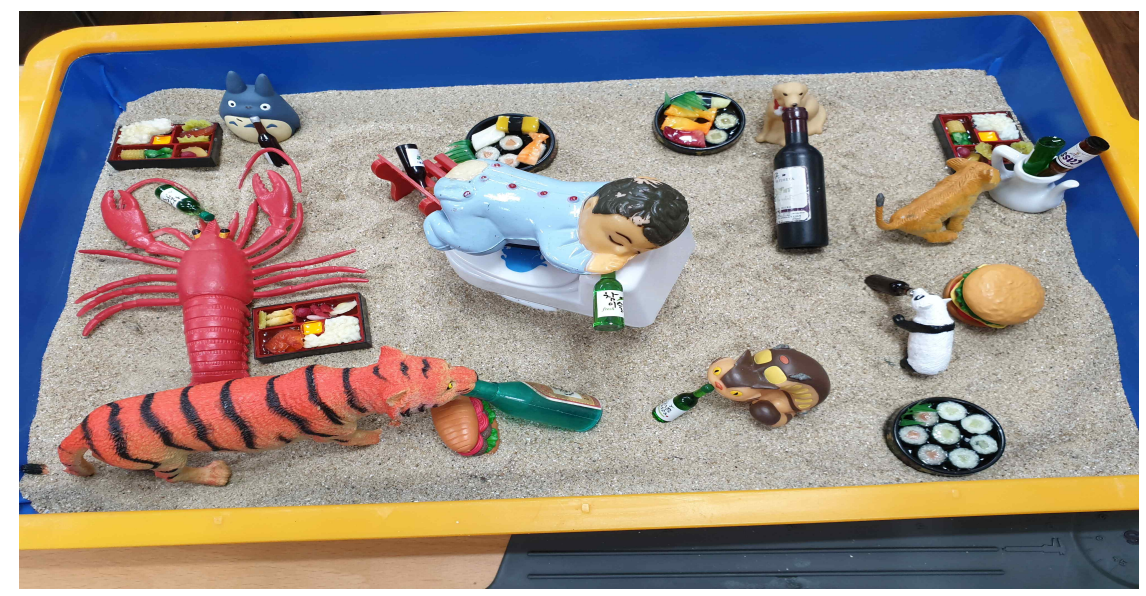

그림 1. 아됭 1회기 모래장면

또한 아기의 좌측에는 다른 동물에 비해 커다란 크기의 붉은색 가재와 호랑이가 술을 먹고 있다.

\section{2) 상상이야기}

"아싸들이 외로워서 술을 마시는 것이다. 인싸를 위하여 ... 아웃사이더는 무리 에서 겉도는 애들이란 것이다. 애네들은 친구다. 이 아기는 2 개월이다. 엄마 아빠 는 이 아기를 안 사랑해준다. 아기가 이런 걸 입고 다녀서 ... 이 아기는 변기에서 
Journal of Symbols \& Sandplay Therapy, Vol.12 No.1.

똥을 싸려고 하는 데 소주가 있어서 먹는 것이다 ... 여기엔 없는데 기자가 이 구 석에 있다. 그래서 사진을 찍어서 인스타에 올린다. 그리고 애네들은 sns 에서 인싸 가 되었다 ... 지금은 우울한데 인싸가 되려고 애네는 노력한다."

그림 1 의 모래장면을 표현한 아동I는 알콜중독증상이 나타나는 부, 오랜기간 우울함을 느 끼고 있는 모와 함께 살고 있다. 모의 보고에 의하면, 부는 COVID-19로 인해 경제적인 어 려움을 겪게 되어서 스트레스를 받는 일이 많아졌으며 술을 먹고 가족들에게 난폭한 행동 을 보일 때가 많아 부부 갈등이 심화되었다고 한다. 아동I는 최근 스마트폰 사용이 많아지 고 조절이 어려워졌으며 모와의 갈등이 많아졌다고 한다.

상상이야기에서 아동I는 외로워서 술을 마시는 것이며, 아무도 아기를 사랑해주지 않는다 고 하였다. 애정, 모성의 결핍을 상징하는(Kalff, 1980) 음식피겨가 놓여진 모래장면과 상상 이야기에서 연구자는 아동I의 극심한 외로움과 돌봄의 결핍, 사랑에 대한 갈망을 느낄 수 있었다. 아동I는 상상이야기에서 외로움과 우울한 상황에서 벗어나기 위해 인싸가 되기 위 한 노력을 한다. 현대 사회에서 많은 아동들이 활동하는 SNS라는 공간에서 인싸가 되고 싶 다는 의미는 아동에게 집에서 홀로 남겨진 자신이 아닌 많은 사람들과 소통하고 그들에게 사랑과 관심을 받고 싶어 하는 아동I의 마음이 그대로 표출된 것이라 느껴졌다.

연구자들은 모래장면에서 다른 동물에 비해 커다란 크기의 붉은색 가재와 호랑이를 보는 순간 압도당하는 느낌을 느꼈다. 모래 장면에 표현된 많은 음식과 동물 피겨들은 모두 술 과 혼합되어 있어 아동I에게 술이 의미하는 것이 무엇일지 생각하게 되었다. 아버지의 알콜 중독, 그것은 아동I의 일상에서 뗄 수 없는 커다란 환경요인일 것이다. 아동I는 어린 시절부 터 부가 술을 먹고 난폭하게 행동하며 모와 갈등을 일으킨 것을 커다란 가재와 호랑이의 모습으로 표현한 것으로 짐작되었다. 모래장면에서 커다랗고 위협적인 존재가 될 수 있는 가재와 호랑이 옆에 있는 아기는 위험해 보이는 데 이것은 아동I가 가정에서 느끼고 있는 정서적인 불안감으로 보인다.

아동가 표현한 모래장면에서 상상이야기한 내용 중 친구이지만 무리에서 겉도는 아웃사 이더라는 이야기, 모래장면 정중앙에 놓여진 아기피겨가 연구자들은 눈에 띄었다. 이것을 보며 아동가 처해진 상황이 이해가 되었다. 고통스러운 현실 속에서 부모는 살기 힘들었기 에 아동I에게 충분한 사랑을 줄 심적인, 물질적인 여력이 없었을 것이라고 예상이 된다. 부 모도 어린 아이 같은 불안정 상태로 짐작이 되며 그런 부모에게 양육되어진 아동I는 충분 한 사랑을 받지 못해 애정 결핍을 느꼈을 것이다. 연구자들은 아동I의 부는 좋지 않은 삶의 환경이 심리적인 고통으로 느껴지고 부정적인 감정과 현실을 마주하고 싶지 않아 술을 먹 는 행동으로 도피하였을 수 있지 않을까란 생각이 들었다. 이와 같은 맥락으로 아동I에게는 불안한 정서와 현실에서 또래관계가 자신이 원하는 대로 되지 않는 등의 어려운 상황과 감 
정을 마주하고 싶지 않아서 스마트폰에 몰입했던 것으로 보인다. 아동가 현실에서 진정으 로 원하는 것은 자신을 사랑해주고 불안을 진정시켜 줄 대상이 필요한 것으로 느껴진다.

아동I는 스마트폰 게임에 몰입하느라 지역아동센터 이용시간에도 지각을 하고 담당사회 복지와도 갈등을 일으켰다. 아동I는 관계 욕구는 있지만 모래장면에서 표현한 것처럼 현실 에서 또래관계의 정서적 교류는 잘 이루어지지 않아서 집단에서 소속되지 못하고 겉도는 느낌이 많았다. 그래서인지 게임에서 만난 가상세계의 관계에 더 집착하는 모습을 보이며 이것은 집단 적응의 어려움으로까지 이어지게 되었다. 아동는 연구자에게도 회기 초반에는 마음을 열지 않는 모습을 보이며 활동에 대해서 설명할 때도 시시하다고 직접적으로 표현 을 하며 집단에서 소속되기 어려워 하는 모습을 보였다. 하지만 회기가 거듭될수록 아동I는 적극적으로 몰입하여 모래장면을 표현하고 이야기하였으며, 친구들에게도 좀 더 호의적으 로 이야기하고 함께 협력해서 모래장면을 만드는 등 친구들과 상호작용했다. 회기 후반으 로 갈수록 책상 밑에 숨는 등의 행동을 보이며 연구자에게 관심을 받으려는 모습도 보이며 집단모래놀이치료가 마무리 될 때는 한 번 더 하고 싶다고 표현하기도 했다. 담당 사회복 지사의 면담을 통해 아동I가 전보다 집단에서 소속감을 더 느끼고 지역아동센터의 규칙 도 잘 지키는 모습을 보여서 사회복지사와의 갈등도 줄어들었으며, 보호자 상담 이후에 개별상담이 진행될 수 있도록 연계되어서 지속적인 개별상담이 이루어진다는 것을 알 수 있었다.

\section{2. 불안에 시달림}

\section{1) 상상의 장면}

뒤집어진 자동차, 옆으로 기울어진 자동차, 겹겹이 쌓여있는 자동차 등 불규칙적이고 무 질서한 모습의 자동차들이 모래장면 속에 놓여있다. 무질서한 자동차는 한쪽 방향으로 쏠 려 있다. 다른 방향에는 아무것도 없다. 몇 대의 자동차들은 모래 속에 파묻혀 있다.

\section{2) 상상이야기}

"자동차 도로를 만들었다. 자동차는 무덤에 간다. 폐차장이다. 자동차들을 다 묻어야 한다. 자동차는 쓸모 없어졌다. 여기는 차들의 영혼이 산다. 폐차장 주인 을 복수하려고 한다. 차들은 안 죽고 싶었는데 죽여서 주인을 복수하려고 한다. 이 차들의 영혼들은 죽여버릴라고 한다. 사람들을 찍어서 죽일거다. 죄 없는 사람 도 죽인다. 화가 나서. 복수를 하고 나면 차에서 영혼이 나온다. 그 사람을 가루 로 만든다. 가루로 만들면 하늘로 올라가서 없어진다. 이 영혼들도 악귀가 되어서 
Journal of Symbols \& Sandplay Therapy, Vol.12 No.1.

죽는다. ... 겁나 좋다. 자동차가 모래에 묻혀있다. 보이면 안 된다(모래로 자동차 를 덮는다). ... 나는 역시 싸이코패스 같다. 사람들을 가끔 죽이고 싶다. 나는 죽 이는 게임도 많이 한다."

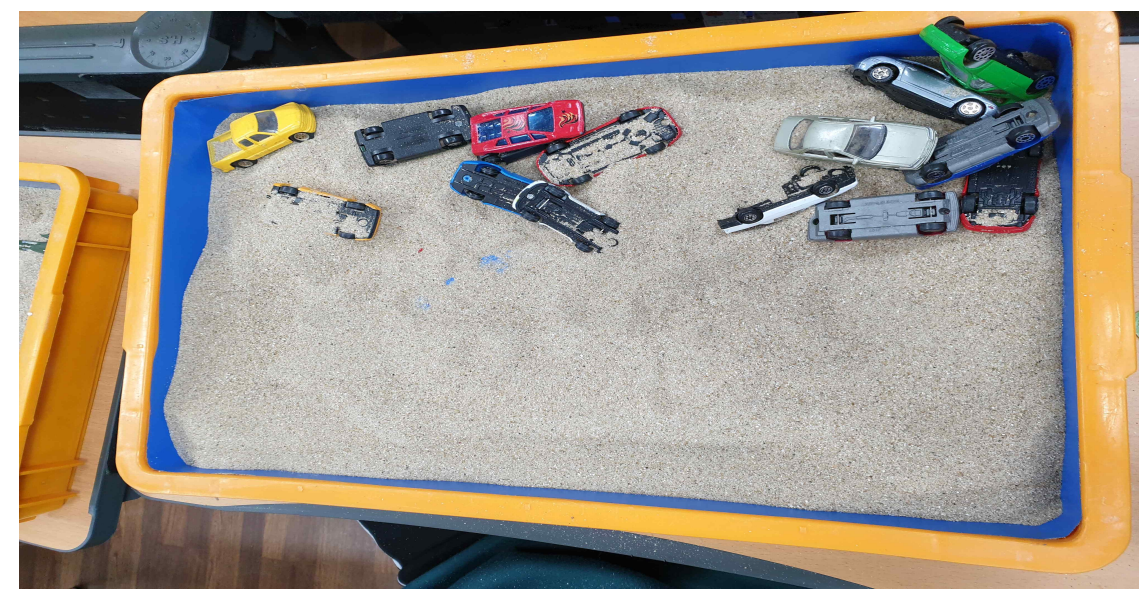

그림 2. 아동D 2회기 모래장면

그림 2의 모래장면을 표현한 아동D는 모에게 방임의 학대를 받은 경험이 있다. 아동 $\mathrm{D}$ 는 엄마가 밥을 챙겨주지 않아서 현재 엄마와 함께 살고 있지 않다고 이야기하였다.

모래장면의 주제가 처음부터 자동차는 아니었다. 집을 만들었다며 가구와 햄버거 등이 올려져 있는 집 안을 모래장면에 표현하였었다. 집과 관련된 생각을 하다가 갑자기 무언가 떠오른 듯 언제 터질지 알 수 없는 화산을 가져오면서 아동 $\mathrm{D}$ 의 표정이 달라짐을 느낄 수 있었다. 아동D의 표정에서는 분노나 불안의 감정이 느껴지기도 하였다. 이런 분노나 불안 의 감정은 무의식 안에 가두어 놓았던 부정적 감정을 화산이라는 피겨를 통해 직면할 용기 를 발달시켰을 것이다. 아동 $\mathrm{D}$ 는 갑자기 화산을 모두 빼더니 자동차를 가져와 놓기 시작하 였다. 내면에 존재하는 복합적인 부정적 감정들이 다이나믹하게 바뀌는 아동 $\mathrm{D}$ 의 감정과 화 산의 파괴, 무질서한 자동차의 이미지를 연결한 것으로 느껴졌다. 통제할 수 없거나 예측할 수 없는 갑작스러운 자동차 사고는 아동D에게는 조절되지 않는 불안함의 표현일 것이다.

아동D는 자동차가 쓸모없어졌다고 하였다. 연구자들은 아동 $\mathrm{D}$ 의 이야기를 통해 부모의 방임으로 인한 존재의 무가치와 분노의 감정을 보여준 것으로 생각해보게 되었다. 한 연구 자는 부모에게 자신은 사랑스러운 존재가 아닌, 쓸모없는 존재로 인식하고 있는 아동D의 마음이 어땠을지 생각해보았다. 안전하지 못한 불안함은 분노의 감정으로까지 연결되었을 것이라고 생각되었고 아동 $\mathrm{D}$ 의 내면에 억압된 분노의 감정은 폐차장 주인에게 복수하는 것 으로 표출되었을 것이라 짐작이 되었다. 결국 자신이 거절당했다는 감정이 분노로까지 이 
어진 것으로 보인다.

아동D는 어린 시절부터 폐렴으로 병원 입원이 잦았다고 한다. 아동 $\mathrm{D}$ 의 보호자는 거동이 불편한 할머니와 가정의 경제를 책임지는 삼촌이었다. 이처럼 삶을 살아내기 각박했던 보 호자는 아동D가 입원했을 때에도 정서적으로나 신체적인 적절한 보살핌을 제공하지 못하 였다. 아동D는 입원했을 때 핸드폰을 가장 많이 했다고 하였다. 아동D에게는 낮선 환경인 병원에서 외로움을 많이 느꼈을 것으로 추측된다. 아동 $\mathrm{D}$ 는 홀로, 쓸쓸히 병원에 남겨졌고, 이때 아동D 옆에 있어 준 대상은 스마트폰 뿐이었다. 퇴원 이후에도 아동 $\mathrm{D}$ 는 일상에서 스 마트폰 사용량은 증가하였고 과도한 스마트폰의 사용은 공격성을 조절하지 못하는 행동의 문제로까지 이어져 친구를 때리는 행동과 연관이 있을 것으로 예측되었다.

사회복지사의 보고에 의하면 화가 나면 친구들을 때리는 아동D의 공격적 행동으로 인해 학교나 지역아동센터에서 지적을 자주 받는 행동이었다고 하였다. 아동는 이 후 회기에 독후감 때문에 선생님께 혼나 화가 난 상태로 집단모래놀이치료에 온 적이 있었다. 감정이 격양된 상태로 이야기하면서 연구자가 하는 말에 집중하지 못하는 모습을 보였다. 그러나 모래상자를 갖다 두고 모래놀이를 시작했을 때는 모래를 만지며 말 없이 집중하였다. 그리 고 모래가 천천히 손에 흘러 내려가는 것을 보면서 “시간이 내려가는 거 같아요. 모래시계 처럼.. 내 화가 내려가는 거 같아요. 기분이 좋아져요.”라고 연구자를 보면서 이야기 했다. 그리고는 모래를 바라보며 미소를 지었다. 회기가 거듭될수록 아동D의 감정이 모래놀이를 하면서 자연스럽게 안정되는 것을 볼 수 있었다. 아동 $\mathrm{D}$ 는 평소에도 목소리가 크고 친구들 을 때리는 등 흥분하는 일이 갖았지만 다른 연구참여자나 연구자가 아동 $\mathrm{D}$ 의 이야기를 들 어줄 때는 말도 천천히 하고 눈 맞춤도 잘 되는 등 정서적으로 안정된 모습을 보였다.

\section{3. 혼자임/소통없음을 견딤}

\section{1) 상상의 장면}

아이가 혼자 누워있다. 주변은 적막하고 사람이 없다. 무언가를 담을 수 있는 통 안에 파 란 색 구슬이 채워져 있고, 절구 같은 모양을 한 피겨 속에 술이 있다. 혼자 누워있는 아이 밑에 스마트폰과 컴퓨터가 있다. 비행기가 구조물 위에 약간 기울어져 걸쳐있다.

\section{2) 상상이야기}

"나는 정원을 만들거다(연못도 가져오고, 노트북 피겨도 가져온다). 애는 영화 를 보는 거다. 비행기가 추락했다. 엔진이 다 떨어졌다. 어느 숲속에 떨어졌다. 여 자애는 혼자 있다. 토로로는 인형인데 말도 할 수 있다. 영화도 보고 이 여자애는 
Journal of Symbols \& Sandplay Therapy, Vol.12 No.1.

성인이다. 애는 소지품을 다 가져왔다. ... 조용할 거 같다. 아무도 없는 거 같아서 좋다. 가족이 간섭해서 가출했다. ... 애가 불쌍해 보인다."

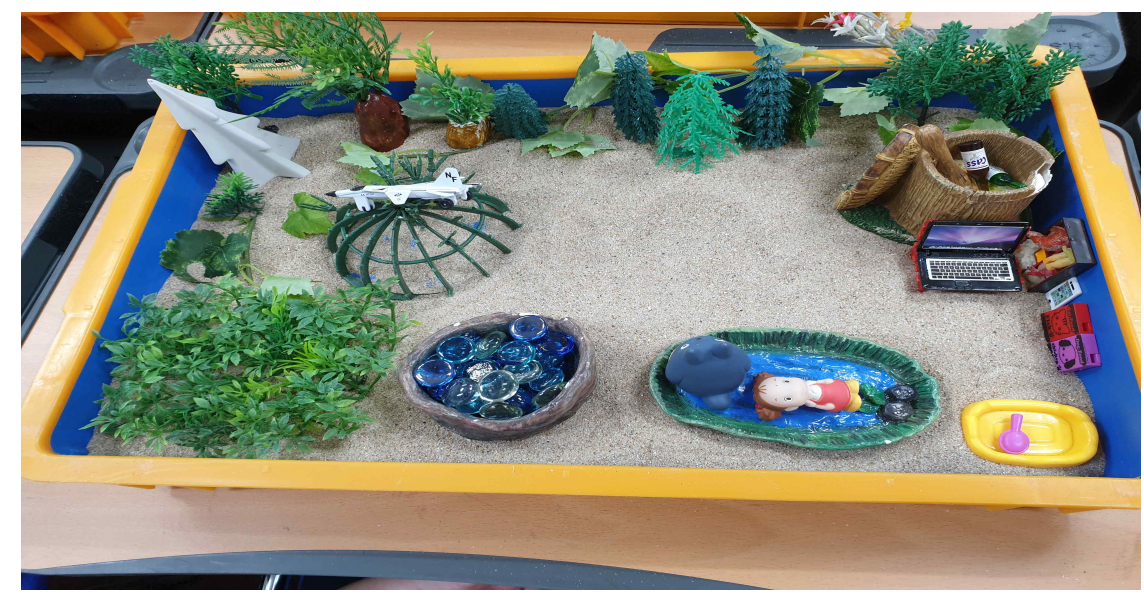

그림 3. 아동C 2회기 모래장면

그림 3의 모래장면을 표현한 아동C는 집에 가기 싫어서 밖에서 놀다가 6시에 집에 들어 간다고 하였고 집에 들어간 이후에는 스마트폰 게임을 하며 저녁 시간을 보낸다고 하였다. COVID-19 때문에 학교에 가지 않아 너무 심심하고, 모가 외출해서 놀지 못하게 한다며 답 답함을 호소하였다. 모는 최근 야근으로 귀가 시간이 늦어지고, 아동C의 오빠는 7 시에 귀가 해서 아동C가 혼자 있는 시간이 많으며 특히 저녁에 혼자 있을 때는 무서움을 느낀다고 하 였다. 그럴 때는 모와 전화 통화하며 무서움을 달랜다고 한다. 아동C는 가끔 스마트폰이 아 동을 지켜주는 거 같다고 표현하였다.

아동C가 혼자임에 소통 없는 상황을 견뎌낼 수 있도록 한 것은 스마트폰의 대표적 기능 인 상호연결성이 있었기에 가능했을 것이다. 아동C는 혼자 있는 시간의 증가로 인해 심심 할 때, 밤에 혼자 있는 시간에 핸드폰을 많이 사용하는 것으로 보여진다. 연구자들은 모래 장면에서도 아동이 느끼는 적막함과 외로움을 느낄 수 있었다. 연구자들은 모래장면에 여 러 종류의 나무들이 놓여있고, 다양한 피겨들이 놓여있음에도 불구하고 허전함이 느껴졌다 는 공통적인 의견을 보였다. 아동C는 모래놀이장면에서 숲 속에 혼자 있고, 소통없음의 관 계를 보이며 외로움을 표현하였다.

아동C의 상상이야기에서 숲 속에 혼자됨과 밤에 혼자 있어야 하는 현실 상황을 연결지어 표현하였다. 집에 혼자인 상황에서 핸드폰 게임으로 소통없음을 달랬던 아동C는 솦 속에 홀로 남겨진 상상이야기를 통해서 숲이 주는 안정감을 표현한 것으로 보인다. 어른들은 외 로울 때 술을 마시고 아이들은 스마트폰을 한다는 아동C의 이야기를 통해 어둠 속에서 오 
롯이 혼자인 시간을 견뎌내었을 아동을 더 깊이 이해하게 되었다.

아동C는 회기 초반에는 앞머리로 얼굴을 가리고 눈 맞춤도 어려웠으며 말도 잘 하지 않 았다. 하지만 아동C는 모래놀이하면서 긴장이 풀리는지 잘 웃기도 하고 다른 연구참여자들 말에도 대답을 잘하였다. 특히 죽고 싶다고 표현하며 우울감을 보이는 다른 연구참여자의 말에 깊이 공감하고 이해해주는 모습을 보였다. 또한 한편으로는 죽고 싶은 감정이 자신만 느끼는 감정이 아니라는 것에 안심하기도 하였다. 이 과정에서 자신의 이야기를 더 개방적 으로 말하면서 관계를 더 깊이 맺는 것을 느낄 수 있었다.

\section{4. 스스로 자신을 보호하기 위해 애슴}

\section{1) 상상의 장면}

모래상자의 모래를 중앙으로 모아서 가운데는 모래가 많고 주변은 상자의 바닥이 보인 다. 총을 든 사람, 활을 쏘는 사람, 도끼를 든 사람, 글러브를 낀 사람이 한쪽 방향을 향하 여 겨누고 있다. 사람들 주위로는 벽이 갈라져 있는 집과 나무들이 있다. 나무 뒤로는 해골 과 뼈가 놓여 있으며 그 뒤에는 호랑이가 나무 뒤에 숨어있다.

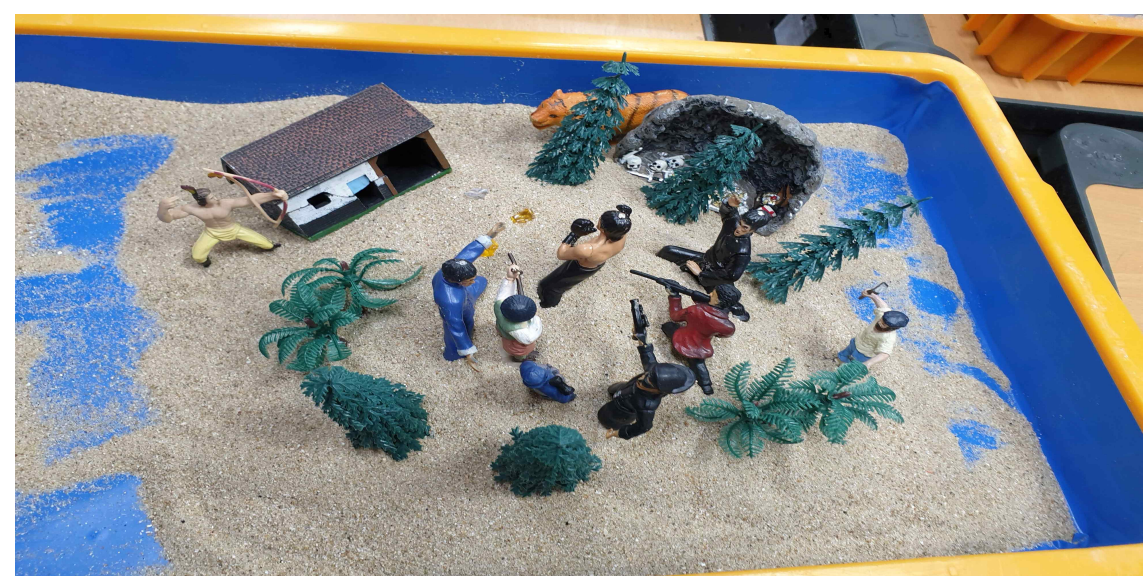

그림 4. 아동E 4회기 모래장면

2) 상상이야기

“섬을 만들고 싶다(모래가 적게 들어간 상자를 택함). 무인도를 만들고 싶다(연 구자가 컵과 빈 모래상자를 주자 아동은 컵에 모래를 덜어서 알아서 모래의 양을 조절하였다) 앤 왕자다(남자 피겨는 횃불, 칼을 들고 있다) ... 음식을 구해서 왔 
Journal of Symbols \& Sandplay Therapy, Vol.12 No.1.

다. 갑자기 무인도로 왔다. 먹을 건 만들었다. 먹을 거 구해가지고 젓가락이 있었 다. 밤에는 횃불을 키고 잔다. 남자는 너무 갑작스럽고 이상한 느낌이었다 ... 애 네는 탈출할 거 같다. 원래 남자가 살았던 도시로 갈 거 같다. 2 년 뒤에는 땅을 넓혔다. 4년 뒤에는(아동은 모래상자에 모래를 더 넣는다) 드디어 땅에 갈 수 있 다. 이제 도시에 간다. 아직 땅을 넓혀야 한다. 그래도 희망이 있다. 6년 뒤 생존 자가 나타난다. 같이 지낼 수 있다. ... 8년 뒤 탈출 못했지만 사람을 찾았다. 생존 자를 찾으면 탈출할 수 있다. 18 년 뒤 호랑이가 잡아먹으려고 한다. 엄마 호랑이 다 ... 사람들은 무섭다. 6명이 힘을 합쳐서 물리치려고 한다."

그림 4의 모래장면을 표현한 아동E의 부모는 청각장애로 인해 아동E에게 관심은 있으나 소통하는데 있어 어려움을 느낄 수 있는 환경이었다. 아동E의 보고를 종합해보면 아동E의 부모는 아동E와 함께 있을 때 부부싸움을 자주 하였다. 부부싸움이 심해졌을 때 모는 아동 $\mathrm{E}$ 를 화장실로 보내었고 아동 $\mathrm{E}$ 는 싸움을 말리고자 경찰에 전화를 걸어 도움을 요청한 경험 도 있었다. 부는 물건을 던졌으며, 옆집 사람들도 오고 경찰도 왔었다며 목소리가 커지고 빠르게 이야기하였다. 스스로 아동 자신의 경험을 회기 중에 자연스럽게 이야기하는 모습 을 보며 오랫동안 아동 $\mathrm{E}$ 를 힘들게 한 사건임을 알 수 있었다. 부부싸움의 상황에서 아동E 는 자신을 지키기 위해 탈출하고 싶었을 것이다. 모래장면에서도 아동는 자신을 보호하기 위한 이미지가 표현되었다.

무인도에서 음식을 구해서 먹고 햇불을 켜 스스로 밤을 지키며 생존하고자 하였다. 또한 잡아먹으려는 호랑이로부터 자신을 보호하고 무인도를 탈출하고자 하였다. 아동E는 스스로 를 지켜야 했고, 스스로를 보호하고자 했던 무의식이 아동의 상상장면, 상상이야기로 나타 난 것으로 보여진다. 연구자 중 한 명은 벽이 갈라져 있는 집, 잡아먹으려는 호랑이를 보며 보호받지 못하는 상황에서 생존하고자 애쓰는 마음이 느껴졌다고 하였다. 또 한 연구자는 부모가 자신의 어려움 앞에 아무런 도움도 주지 않을 때 큰 상실감으로부터 자신을 지키고 자 하는 아동E의 마음이 느껴졌다고 하였다. 아동E에게 핸드폰은 마치 부모를 대신한 말동 무이자 혼자 있는 시간의 외로움을 달래주는 도구, 때로는 햇불처럼 어두운 밤을 밝혀주는 도구 등 여러 가지 의미를 가지고 있을 것이다.

아동E의 부모는 청각장애인이기도 하고, COVID-19로 인해 대면상담이 아닌 전화상담을 해야하는 환경적 여건으로 부모상담을 진행하기 어려운 상황이었지만, 영상전화를 통해 수 어통역사가 모와 연구자의 대화를 전달하여 의사소통을 할 수 있었다. 모는 아동E와 소통 이 안 되는 것에 대해 힘들다고 호소하였다. 모는 그 이유가 자신이 말을 하지 못하고, 아 동E는 깊은 대화를 할 수 있을 만큼 수어를 할 수 없기 때문에 소통이 어렵다고 생각하고 있었다. 연구자는 모에게 아동의 또래연령이 갖는 발달상의 특징과 아동의 연령에서 정서 
적인 표현을 언어로 모두 전달하기 어렵다는 것에 대해 이야기하였다. 그러자 모는 자신의 자녀와 자신만의 문제만이 아니라는 것에 안심하는 모습을 살펴볼 수 있었다. 모는 자신과 대화하기를 거부하고 아동가 스마트폰에만 집착하는 것이 부모가 가지고 있는 청각장애 때문이라고만 생각해서 오랜기간 고민하고 힘들게 한 것으로 보였다. 연구자는 가정에서 모와 자녀가 함께 스마트폰 사용시간에 대한 규칙을 세우고, 다른 놀이를 함께 할 수 있도 록 권하였다. 아동과 자연스럽게 놀이를 하면서 관계를 맺는 시간을 갖고 아동에게 정서 적인 관심을 준다면 더 원활한 소통이 될 것이라고 이야기했다. 이 가족의 경우 소통의 욕 구는 있으나 부모가 가진 장애와 아동의 발달 특성에 대한 인식 부족, 아동의 연령에 맞는 적절한 소통방법을 알지 못해 가족 간의 정서적 관계가 더욱 단절되었던 것으로 보인다.

그 이후 회기 집단모래놀이치료에서 아동는 핸드폰 사용시간을 줄이기로 한 모와의 약 속을 지키며 자신은 이제 스마트폰 중독에서 벗어났다고 스스로 뿌듯해하는 모습을 볼 수 있었다. 그것은 아동의 상상이야기 속 혼자 있던 무인도에서 사람들과 탈출하여 땅으로 올 라서는 모습처럼 다른 사람들과 더 소통하고 관계하면서 정서적으로도 연결되는 것으로 보 여졌다.

\section{IV. 결 론}

본 연구는 부모를 포함한 보호자의 낮 동안의 부재 그리고 그로 인해 인터넷, 스마트폰 과의존 현상이 심각해진 지역아동센터 아동들을 대상으로 COVID-19 팬데믹 시기 동안 집 단모래놀이치료를 실시하였다. 이 과정에서 집단모래놀이치료가 아동들을 인터넷, 스마트폰 과의존에 빠지게 만든 심리적 어려움을 완화하며 인터넷, 스마트폰 과의존 현상을 어느 정 도 해결할 수 있을지 그리고 그 과정에서 어떤 상징들이 출현할지에 대해 Jung학파 분석심 리학적 관점에서 집단모래놀이치료 과정으로 연구하였다.

COVID-19를 경험하는 인터넷, 스마트폰 지역아동센터 아동의 집단모래놀이치료에서의 연구결과는 '사랑받고 싶음, '불안에 시달림, '혼자임/소통없음을 견딤' '스스로 자신을 보 호하기 위해 애씀 총 네 가지의 공통된 주제를 보였다. 구체적으로 이 연구결과를 통해 연 구자들이 알 수 있었던 것은 다음과 같다.

첫 번째, 창조적 놀이의 형태이자 예술의 요소를 가지고 있는 자발적인 모래놀이 과정을 통해 연구참여자들의 정서가 잘 표현되었으며 이로 인해 그들의 정서를 더 잘 이해할 수 있었다.

연구참여자들의 공통된 주제들은 모래놀이 과정에서 다양한 상징으로 나타났다. 연구참 여자들이 자발적으로 만들어낸 상상장면과 상상이야기는 예술이 가진 요소가 포함되어 있 
Journal of Symbols \& Sandplay Therapy, Vol.12 No.1.

었다. 예술은 창조적인 요소를 포함하고 있고, 그것들 모두에서 놀이 요소를 찾아볼 수 있 다는 말(Huizinga, 1983)처럼 아동들의 예술작품에서 창조적인 요소와 놀이를 알 수 있었으 며 무의식이 포함된 상징은 아동들의 정신을 좀 더 이해할 수 있었다. Winicott은 놀이가 상상일 뿐 아니라 개인적 현실에 대한 관계와도 연결되어 있다(Winnicott, 1991)고 했다. 그 들의 놀이에서는 아동의 상상이지만 그 안에는 현실이 반영되어 있었다. 본 연구에서도 연 구참여자들의 모래장면, 모래장면에 대한 상상이야기와 그들의 표정과 행동을 통해 아동들 의 생생한 정서적 감정을 느낄 수 있었다. 또한 상징과 상상이야기를 표현하는 과정 안에 서 정서뿐만 아니라 연구참여자들이 현재 처한 상황을 이해하고 공감할 수 있었다.

모래놀이치료 과정에서 표현되는 상징이 감성적으로 의미를 갖게 될 때 이는 연구자의 관심이 전달되며 이를 예술, 문학, 대화 등을 통해 인식하게 된다(Kast, 1992)고 하였는데, 본 연구결과에서도 살펴볼 수 있었다. 연구참여자들이 표현한 예술작품이라 할 수 있는 모 래놀이 장면을 통해 예술이 갖고 있는 의미처럼 보는 이로 하여금 공감대를 형성하였다. 이러한 결과는 아동들이 자신의 심리 정서적 어려움을 성인에 비해 언어로만 표현하는 것 에 한계가 있기 때문에 예술을 심리적 탐구의 수단으로 사용하는 것은 예술적 표현이 구어 가 접근할 수 없는 방식으로 어려움을 더 이해하고 해결할 수 있음(McNiff, 2011)을 잘 보여 주고 있다. 연구참여자들과 언어로만 작업했다면 알 수 없는 것이었지만 이미지와 모래놀 이 과정의 비언어적인 부분을 통해 아동의 욕구를 더 잘 알아차릴 수 있었고 감정에 다가 갈 수 있었다.

국외선행연구에서 예술기반의 질적연구를 통해 아동들의 정서 상태를 논의하였다. COVID-19 발생 시 아동의 그림 그리는 방법을 통한 예술기반 연구(Abdulah et al., 2020)에서 아동들은 COVID-19 발생 전에 했던 정상적인 활동을 할 수 없기 때문에 외로움과 우울함 을 느낀다는 선행연구결과는 본 연구와 유사한 결과를 보였다. 또한 아동들은 또래관계를 필요로 하며 놀이, 그림 그리기 같은 창조적인 활동을 통해 그들의 감정을 표현할 수 있는 긍정적인 방법을 찾을 수 있도록 권고하였다. 이는 창조적 놀이의 형태인 모래놀이와 같이 자유롭게 자신의 심리적 어려움을 상징으로 표현하는 것의 필요성을 강조해 준다.

두 번째, 아동의 개별적인 모래놀이 장면과 상상한 이야기를 면밀하게 살펴봄으로써 그 들을 둘러싼 환경, 가족들 간의 관계에 큰 영향을 받고 있음을 알 수 있었으며, 이들에게는 개인 뿐 아니라 사회적인 지지체계가 필요하다는 것을 시사한다.

지역아동센터 아동을 중심으로 사회적 지지가 스마트폰 중독에 미치는 영향을 연구한 선 행연구(조명순, 고윤순, 2016)결과 사회적 지지의 하위영역인 가족지지, 친구지지, 학교교사 지지, 지역아동센터 교사 지지는 개별적 전체적으로 아동의 스마트폰 중독에 부적인 영향 을 미쳐 스마트폰 중독 예방과 개입에 사회적 지지가 필요함을 나타내었다. 특히 하위변인 중 학교 교사 지지의 영향력이 더 큰 것으로 나타난 것은 아동들이 학교에서 보내는 시간 
이 상대적으로 더 많기에 보여진 결과로 추측된다고 하였다. 하지만 지금처럼 COVID-19로 인해서 학교에 가지 않고 온라인 수업을 하는 기간에는 학교 교사 지지보다 지역아동센터 의 교사, 가족지지가 더 중요 할 것으로 사료된다. 본 연구에서 참여자들은 학교나 지역아 동센터에 오가지 않는 주말에 가장 오랜 시간 인터넷, 스마트폰을 한다고 보고하였다. 따라 서 지역아동센터 내에서 스마트폰을 할 수 없는 규칙은 이들에게 인터넷, 스마트폰 과의존 예방에 보호요인임을 짐작할 수 있었다. 그리고 가정 내에서 스마트폰을 대신할 수 있는 놀이 환경 마련의 필요성 및 스마트폰 중독 예방과 관련된 부모교육과 면담이 이루어져야 함을 느낄 수 있었다. 아동들에게 능동적으로 자발적인 행위를 할 수 있는 놀이의 기회를 제공하는 것이 필요함을 안내하고 가정에서도 상상과 창조성이 자연스럽게 표현될 수 있는 놀이환경의 마련이 필요하며 어른들의 관심이 이들에게 지지체계가 된다는 것을 알 수 있 었다. 이는 인터넷, 스마트폰 사용은 개인적인 문제이지만 사회적 측면이 충분히 반영되어 야 한다는 것을 뜻한다. 따라서 온라인 수업, 사회적 거리두기가 시행되는 COVID-19 팬데 믹 시대를 살아가는 스마트폰, 인터넷 과의존 아동들에게 사회적 관점에서 구체적이고 효 율적 개입 방안 마련이 시급할 것으로 사료된다.

세 번째, 아동들은 외로움과 고립감을 느꼈고, 누군가와 함께 하고 싶은 마음이 절실했으 며 그것이 충족되지 않을 때 인터넷, 스마트폰에 더 몰입하게 된다는 것을 알 수 있었다. 특히 지역아동센터 이용 아동들은 COVID-19 팬데믹 시기 이전에도 혼자 있는 시간의 외로 움과 관계의 단절을 경험하였는데 COVID-19로 인해 낮 시간 동안 학교도 가지 않고 집에 있는 시간이 길어지면서 외로움의 감정은 심화됨을 알 수 있었다. 이와 같은 결과는 기존 의 선행연구(황중원, 김진숙, 2017; 변희숙, 권순용, 2014)에서도 외로움을 많이 느낄수록 스 마트폰의 과의존 현상이 심화될 수 있음과 맥락이 같다. 아동들은 집에 있으면서도 가족과 함께 상호작용하는 시간보다 혼자 지내거나 스마트폰으로 연결된 친구들과 시간을 보내는 경우가 많았다. COVID-19로 인해 생겨난 여러 심리적 스트레스를 조절하는 데 실패한다면 원래 지니고 있는 스트레스는 더 악화된다(김현수, 2020)는 선행연구결과를 바탕으로 아동 들이 겪는 관계단절이 트라우마로 자리 잡기 전에 적극적으로 개입해야 할 필요성을 강조 해준다.

네 번째, 예술작업과 같은 모래놀이에서 집단에서의 수용적인 관계와 치료자의 상호주관 성은 이들에게 치유가 일어나는 데 필요한 것임을 인식할 수 있었다. 따라서 인터넷, 스마 트폰 과의존 행동이 모래놀이를 통한 창조적이고 치유적인 개입에 대한 긍정적인 기대를 하게 되었다.

이는 국외선행연구에서도 보여진다. 선행연구 결과에서 어린 시절 재난 생존자의 트라우 마 후 성장을 어떻게 인식하는지, 그리고 그들의 정신적 충격적 경험에 의미를 부여하는 데 예술을 이용하였다(Mohr, 2014). 이 선행연구결과에서도 예술은 탐구와 치유의 주요 원천 
Journal of Symbols \& Sandplay Therapy, Vol.12 No.1.

으로 예술치료의 개입이 연구참여자에게 자연스러운 치유의 경험이 됨을 보여주어 본 연구 결과와 일치한다. 본 연구에서 모래놀이치료는 아동에게 놀이는 정신적으로 발달하는 원형 적인 것이며 원형적 에너지의 배열은 정서적으로 경험되고 치유와 변화를 가져오는 것이라 할 수 있다(장미경, 이여름, 2020). 다시 말해서 연구참여자가 표현한 예술작품이라 할 수 있는 모래장면과 상상한 이야기를 치료자가 공감해주고 수용해줄 때 아동은 내적 갈등이 야기한 심리적인 어려움을 완화되는데 효과적일 것이며 아동이 무의식의 추동으로부터 덜 시달리고 행동의 개선이 생김과 동시에 치유가 일어날 것이다(장미경, 2018). 여기에서 치료 자와 연구참여자의 상호주관성은 치유에서 중요한 역할을 한다. 특히 분석심리학에서 치료 자의 깊은 직관은 진정한 참된 지식을 제공할 수 있는 것이며, 단지 추측이나 짐작 또는 공상이 아니다(Stein, 2015). 따라서 치료자는 수용적인 분위기와 치료적인 직관을 이용해서 아동들의 상징을 이해하려고 노력하는 태도가 필요함을 알 수 있었다.

본 연구의 제한점은 경기도 지역에 거주하는 지역아동센터를 이용하는 연구참여자를 중 심으로 진행하였다. 다양한 지역이 아니라 특정한 지역에서만 연구가 이루어졌으므로 이것 이 지역아동센터 이용 아동의 심리적 특성을 일반화하기에는 한계가 있다. 또한 본 연구에 서 연구참여자와 진행된 6 회기와 1 회에 그친 보호자 면담이 추후 연구에서 더 길게 이루어 진다면 아동과 아동의 환경을 이해하고 개입하는 데 도움이 될 것이라 생각한다.

본 연구는 아직도 종식되지 않은 COVID-19 시대를 살아가는 인터넷, 스마트폰 과의존 연구참여자들에게 집단모래놀이치료과정을 보다 생생하게 이해할 수 있도록 예술기반 연구 를 실시하였다는 데에 그 가치가 있다. 국내 아동들을 대상으로 예술기반 연구가 미흡한 상황에서 시도한 연구이기 때문에 추후 연구의 기초가 될 것이다. 또한 이후 인터넷, 스마 트폰 과의존 아동들과 집단프로그램을 진행할 때 현장에서 실질적으로 활용할 수 있는 정 보를 제공할 수 있을 것이다.

\section{참고문헌}

강은영 (2009). 예술기반 교육연구 방법론에 관한 고찰. 예술교육연구, 7(1), 45-59.

권장희 (2018). 스마트폰으로부터 아이를 구하라. 서울: 마더북스.

김성민 (2017). 분석심리학과 문학. 신학과 실천, $53,217-254$.

김양수 (2017). 성인애착이 스마트폰 중독에 미치는 영향: 외로움과 자기 통제력의 매개효

과. 인천대학교 대학원 석사학위논문.

김지현 (2021.02.09.). “코로나19인터넷 · 스마트폰 중독 키운다". 금강일보.

http://www.ggilbo.com/news/articleView.html?idxno=827621. 2021. 04. 27 인출. 
김현수 (2020). 코로나로 아이들이 잃은 것들. 서울: 알피스페이스.

문다영 (2020.09.08.). 거리두기가 최우선 된 초등교실... “술래잡기 대신 혼자 색칠만”. 연합뉴

스. https://n.news.naver.com/article/001/0011866861. 2021. 04 .24 인출.

박소정 (2020). 전래동화 <해와 달이 된 오누이>를 통한 자살사고에 대한 예술기반 연구.

교육인류학연구, 23(3), 111-162.

변희숙, 권순용 (2014). 초등학생의 외로움과 스마트폰 중독이 학교생활적응에 미치는 영향:

스마트폰 중독의 매개효과. 아동교육, 23(4), 303-317.

백수정 (2016). 집단 창작 중심 음악치료가 지역아동센터 아동의 자아존중감과 자아탄력성

에 미치는 영향. 성신여자대학교 대학원 석사학위 논문.

소혜진 (2020). 예술치료에서의 예술기반 연구방법 활용에 대한 탐색. 신체심리연구, 6(1), 37-56.

손은경, 최은영, 공마리아 (2016). 초등학교 고학년의 스마트폰 중독 위험성이 정신건강에

미치는 영향에 있어 회복탄력성의 매개효과. 재활심리연구, 23(2), 439-457.

여성가족부 (2020). 정책뉴스: 2020년 인터넷.스마트폰 이용습관 진단조사.

이미정 (2017). 예술기반 연구방법에서 바라보는 예술의 가치. 미술교육연구논총, 50(1), 47-72. 이현주, 채선미, 방경숙, 최희승 (2015). 학령전기 아동의 스마트폰 중독경향과 문제행동 및

어머니 양육효능감과의 관계. 아동간호학회지, 21(2), 107-114.

임숙희, 신현지 (2020). 우울, 불안 및 외로움의 변화가 스마트폰 중독의 변화과정에 미치는

영향. 한국심리학회지, 25(1), 273-286.

장미경 (2017). 분석심리학적 모래놀이치료. 서울: 학지사.

장미경 (2018). 놀이치료. 서울: 창지사

장미경, 이여름 (2020). 놀이의 신성성과 치유 목적성. 상징과 모래놀이치료, 11(2), 1-43.

전애영 (2019). 집단모래놀이치료의 실제. 서울: 피와이메이트.

정낙림 (2017). 놀이하는 인간의 철학. 서울: 책세상.

정낙림 (2012). 니체와 현대 예술. 서울: 역락.

정익중, 이수진, 강희주 (2020). 코로나 19로 인한 아동일상 변화와 정서 상태. 한국아동복지

학, 69(4), 56-90.

조명순, 고윤순 (2016). 사회적 지지가 빈곤아동의 스마트폰에 미치는 영향: 지역아동센터

아동을 중심으로. 학교사회복지, 16(36), 175-199.

한국정보화진흥원 (2015). 2015년 스마트폰 과의존 실태조사 결과.

홍명희 (2005). 상상력과 가스통 바슐라르. 경기: 살림출판사.

황중원, 김진숙 (2017). 아동의 외로움이 스마트폰 중독현상에 미치는 영향. 인문사회, 8(4), 693-706. 
Journal of Symbols \& Sandplay Therapy, Vol.12 No.1.

Abdulah, D. M., Abdulla, B. M. O. \& Liamputtong, P. (2020). Psychological response of children to home confinement during COVID-19: A qualitative arts-based research. The International journal of social psychiatry, 12, 1-9.

Barone, T. \& Eisner, E. (2012). Arts based research. Thousand Oaks, CA: Sage.

Beer, L. E. (2016). From embedded to embodied: Including music in arts-based music therapy research. Music Therapy Perspectives, 34(1), 33-40.

Boik, B. L. \& Goodwin, E. A. (2000). Sandplay therapy: a step-by-step manual for psychotherapists of diverse orientations. New York: W. W. Noton \& Company. (Trans. into Korean in 2012).

Caldwell, L. \& Joyce, A. (2011). Reading Winnicott. London: Routledge. (Trans. into Korean in 2015).

Eisner, E. W. (2005). Does Arts-based Research Have a Future?. Studies in Art Education, 48(1), 9-18.

Erickson, J. M. (1991). Wisdom and the Senses. New York: W. W. Noton \& Company. (Trans. into Korean in 2008).

Huizinga, J. (1983). Homo Ludens: A Study of the Play Element in Culture. Boston: The Beacon Press. (Trans. into Korean in 2010).

Jung, C. G. (1984). Archetyp und Unbewußtes. Princeton: Bollingen/Princetonn University Press. (Trans. into Korean in 2002).

Jung, C. G. (1985). Erlosungsvorstellungen in der Alchemie. Walter: Olten. (Trans. into Korean in 2004).

Jung, C. G. (1990). Mensch und Kultur. Walter: Olten. (Trans. into Korean in 2004).

Jung, C. G. (1996). Man and His Symbols. New York: J. G. Ferguson Publishing. (Trans. into Korean in 2007).

Kalff, D. M. (1980). Sandplay. Boston, MA: Sigo Press.

Kast, V. (1992). The dynamics of symbols: fundamentals of Jungian psychotherapy (Schwartz, S. A., Trans.). New York: Fromm International.

Leavy, P. (2008). Method meets art. New York: Guilford Press.

Leavy, P. (2015). Methoth Meets Art: Arts-Based. Research Practice. New York: Guilford Press. (Trans. into Korean in 2018).

Malchiod, C. A. \& Crenshaw, D. A. (2013). Creative Arts Play Therapy for Attachment Problems. New York: Guilford Press. (Trans. into Korean in 2019).

McNiff, S. (1988). Art-based research. London: Jessica Kingsley Publishers.

McNiff, S. (2011). Artistic expressions as primary modes of inquiry. British Journal of Guidance \& Counselling, 39(5), 385-396.

Mohr, E. (2014). Posttraumatic Growth in Youth Survivors of a Disaster: An Arts-Based Research 
박성민·조 윤·정현경 / COVID-19 팬데믹 시대를 경험하는 인터넷, 스마트폰 가의존 지역아동센터 아동의 집단모래놀이치료에 대한 예술기반 연구

Project. Art Therapy: Journal of the American Art Therapy Association, 31(4), 155-162.

Nachmanovitch, S. (1990). Free Play. New York: Peguin Group. (Trans. into Korean in 2008).

Punnett, A. (2018). Jungian Child Analysis. New York: Fisher King Press.

Stein, M. (2015). Jung's Map of Seoul. Chicago, I 1: Open Court. (Trans. into Korean in 2015).

Susan, R. \& Joel, W. (2021). Jungian arts-based research and the nuclear enchantment of New Mexico. London/New York: Routlege.

Winnicott, D. W. (1991). Playing and Reality. London: Tavistock. (Trans. into Korean in 1997). 